\title{
Volatiles from the hypoxylaceous fungi Hypoxylon griseobrunneum and Hypoxylon macrocarpum
}

\author{
Jan Rinkel ${ }^{1}$, Alexander Babczyk ${ }^{1}$, Tao Wang ${ }^{1}$, Marc Stadler ${ }^{2}$ and Jeroen S. Dickschat ${ }^{* 1}$
}

\author{
Full Research Paper \\ Address: \\ ${ }^{1}$ Kekulé-Institut für Organische Chemie, Universität Bonn, \\ Gerhard-Domagk-Straße 1, 53121 Bonn, Germany and ${ }^{2}$ Abteilung \\ Mikrobielle Wirkstoffe, Helmholtz-Zentrum für Infektionsforschung, \\ Inhoffenstraße 7, 38124 Braunschweig, Germany \\ Email: \\ Jeroen S. Dickschat ${ }^{*}$ - dickschat@uni-bonn.de \\ * Corresponding author \\ Keywords: \\ constitutional isomerism; gas chromatography; mass spectrometry; \\ natural products; volatiles \\ Beilstein J. Org. Chem. 2018, 14, 2974-2990. \\ doi:10.3762/bjoc. 14.277 \\ Received: 17 October 2018 \\ Accepted: 22 November 2018 \\ Published: 04 December 2018 \\ Associate Editor: A. Kirschning \\ (c) 2018 Rinkel et al.; licensee Beilstein-Institut. \\ License and terms: see end of document.
}

\begin{abstract}
The volatiles emitted by the ascomycetes Hypoxylon griseobrunneum and Hypoxylon macrocarpum (Hypoxylaceae, Xylariales) were collected by use of a closed-loop stripping apparatus (CLSA) and analysed by GC-MS. The main compound class of both species were polysubstituted benzene derivatives. Their structures could only be unambiguously determined by comparison to all isomers with different substitution patterns. The substitution pattern of the main compound from H. griseobrunneum, the new natural product 2,4,5-trimethylanisole, was explainable by a polyketide biosynthesis mechanism that was supported by a feeding experiment with $\left(\right.$ methyl- $\left.{ }^{2} \mathrm{H}_{3}\right)$ methionine.
\end{abstract}

\section{Introduction}

Fungi release a large number of different volatiles that belong to all kinds of natural product classes [1]. Many of these compounds are of interest, because they are markers for the production of fungal toxins and thus can help to distinguish between toxigenic and closely related non-toxigenic species. For example, the sesquiterpene trichodiene (1, Figure 1) is the precursor of the trichothecene family of mycotoxins [2], a class of highly bioactive secondary metabolites that belong to the strongest known inhibitors of protein biosynthesis in eukaryotes [3]. Similarly, the sesquiterpene aristolochene (2) is the parent hydrocarbon of PR toxin [4,5] and has been used as a marker to differentiate between toxin producing and non-producing Penicillium roqueforti isolates [6]. On the other hand, fungal volatiles are interesting, because they contribute with their aroma to the flavour of many edible mushrooms. One of the first identified and certainly most widespread compounds is matsutake alcohol, $(R)$-oct-1-en-3-ol (3), that is produced inter alia by Tricholoma matsutake [7], a highly sought delicacy in the Japanese cuisine, the bottom mushroom Agaricus bisporus, and the penny bun Boletus edulis [8], as the name indicates a European equivalent to Matsutake in high-class cooking. Volatile organic compounds are also important in the interaction be- 


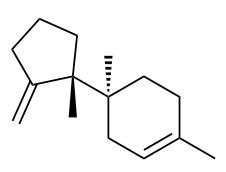

1

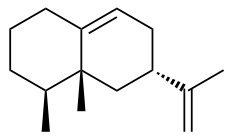

2

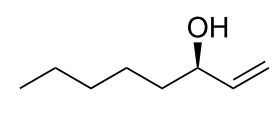

3

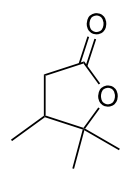

4

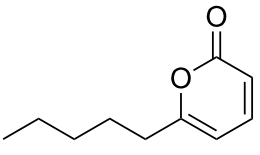

5

Figure 1: Structures of fungal volatiles. Trichodiene (1), aristolochene (2), $(R)$-oct-1-en-3-ol (3), 3,4-dimethylpentan-4-olide (4), and 6-pentyl-2Hpyran-2-one (5).

tween different species, e.g., between ophiostomatoid fungi and conifer bark beetles that show different behavioural responses to fungal volatiles [9]. Fungal volatiles can also be of importance in the interaction between plants and fungi. In some cases, fungal volatiles seem to be involved in the plant pathogenicity of fungi, as recently observed for 3,4-dimethylpentan-4-olide (4), a volatile from the ash pathogen Hymenoscyphus fraxineus that currently threatens the European ash population [10]. Both enantiomers of this lactone were found to inhibit ash seed germination and to cause necrotic lesions in the plant tissue. In other cases, fungal volatiles can have beneficial effects and may even be involved in the induction of systemic resistance in plants, as can be assumed for 6-pentyl-2H-pyran-2-one (5) that is produced by many fungi from the genus Trichoderma $[11,12]$.

Fungal volatiles can be efficiently analysed by trapping, e.g., on charcoal filters with a closed-loop stripping apparatus (CLSA) that was developed by Grob and Zürcher [13], followed by filter extraction and GC-MS analysis of the obtained headspace extracts [14]. The unambiguous compound identification requires a good match of the recorded electron impact (EI) mass spectrum to a database spectrum and of the retention index, a standardised GC retention factor that is calculated from the retention times of the analytes and of $n$-alkanes [15], in comparison to an authentic standard or published data. A peculiar problem in the analysis of aromatic compounds with multiple substituents is that constitutional isomers with the same types of substituents, but different substitution patterns often have very similar mass spectra. Furthermore, some of the isomers may also have similar retention indices, and therefore it is mandatory for unambiguous structure elucidation to compare analytes that fall into this class to all the possible isomers. A similar problem can apply to the structural assignment of compounds with multiple stereocentres based on GC-MS data, because the various possible diastereomers usually also produce very similar mass spectra [16], a phenomenon that is also reported for $E$ and $Z$ stereoisomers and can lead to wrong structural assignments, if no authentic standards are used for comparison [17]. We have recently reported on two chlorinated aromatic compounds from an endophytic Geniculosporium sp. [18] and on a series of structurally related phenols, benzaldehydes and anisole derivatives from Hypoxylon invadens [19] that could only be identified with certainty following this approach of extensive compound comparisons. Members of the family Hypoxylaceae are regarded to be extremely rich in secondary metabolites [20], but not much is known about volatiles from these fungi [21]. In continuation of this work, here we present the volatiles emitted by Hypoxylon griseobrunneum MUCL 53754 and Hypoxylon macrocarpum STMA 130423. These strains were selected, because both species released a characteristic and strong odour, as was already mentioned in the literature for H. macrocarpum $[22,23]$, but the nature of the odoriferous compounds remained unknown. As will be shown, the bouquets of both species are composed mainly of highly substituted aromatic compounds whose structures were only securely identifiable by comparison to all the possible constitutional isomers with different ring substitution patterns.

\section{Results and Discussion Headspace analysis}

The volatiles released by agar plate cultures of $H$. griseobrunneum and H. macrocarpum were collected using a CLSA [13]. After a collection time of one day the charcoal filter traps were removed and extracted with $\mathrm{CH}_{2} \mathrm{Cl}_{2}$, followed by $\mathrm{GC}-\mathrm{MS}$ analysis of the obtained extracts. For both strains a large number of compounds from different compound classes including alcohols, ketones, esters, terpenes and pyrazines were identified. Besides the observed minor production of compounds from these classes aromatic compounds dominated, but the patterns were strain-specific.

\section{Identification of volatiles from Hypoxylon griseobrunneum}

A representative total ion chromatogram for the volatiles released by Hypoxylon griseobrunneum is shown in Figure 2 and the results of the analysis are compiled in Table 1. Several compounds in the headspace extract were readily identified from their mass spectra and retention indices, including the widespread alcohol 2-methylbutan-1-ol (6) as one of the main compounds and traces of the corresponding acetate ester 7 (Table 1 and Figure 3). Small amounts of matsutake alcohol (3) were 


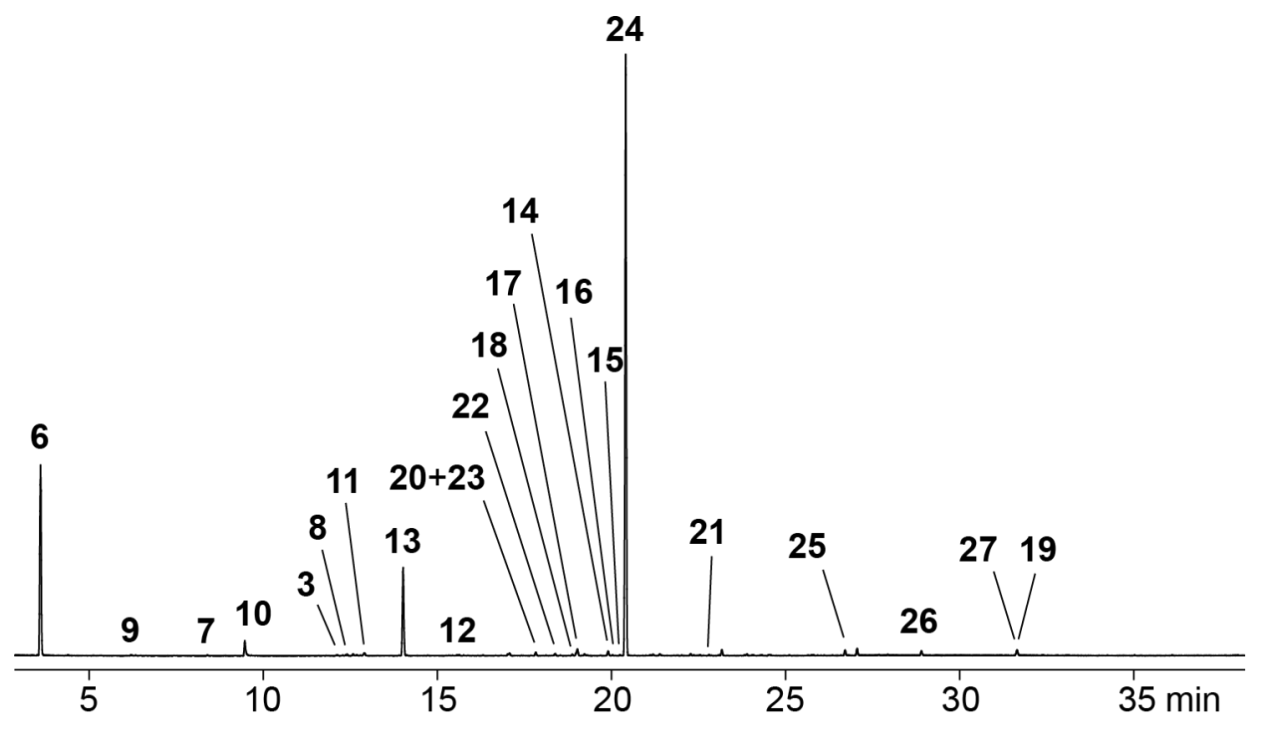

Figure 2: Total ion chromatogram of a CLSA headspace extract from Hypoxylon griseobrunneum MUCL 53754. Peak numbers refer to compound numbers in Table 1 and in Figure 3.

Table 1: Volatiles identified in the headspace extract from Hypoxylon griseobrunneum MUCL 53754.

\begin{tabular}{|c|c|c|c|c|}
\hline compound & $\rho^{a}$ & I (lit.) & identification $^{\mathrm{b}}$ & peak area $^{\mathrm{c}}$ \\
\hline 2-methylbutan-1-ol (6) & 723 & $724[25]$ & $\mathrm{ms}$, ri, std & $18.6 \%$ \\
\hline methylpyrazine (9) & 817 & 819 [25] & ms, ri, std & $<0.1 \%$ \\
\hline 2-methylbutyl acetate (7) & 874 & $875[25]$ & $\mathrm{ms}$, ri, std & $<0.1 \%$ \\
\hline 2,5-dimethylpyrazine (10) & 903 & $908[25]$ & ms, ri, std & $1.5 \%$ \\
\hline oct-1-en-3-ol (3) & 974 & $974[25]$ & $\mathrm{ms}$, ri, std & $<0.1 \%$ \\
\hline octan-3-one (8) & 982 & 979 [25] & $\mathrm{ms}$, ri, std & $<0.1 \%$ \\
\hline trimethylpyrazine (11) & 995 & $1000[25]$ & $\mathrm{ms}$, ri, std & $0.2 \%$ \\
\hline 1,8-cineole (13) & 1027 & $1026[25]$ & $\mathrm{ms}$, ri, std & $8.5 \%$ \\
\hline 2-ethyl-3,6-dimethylpyrazine (12) & 1074 & $1077[24]$ & ms, ri, syn & $<0.1 \%$ \\
\hline veratrole $(20)$ & 1141 & $1141[25]$ & ms, ri, std & $0.2 \%$ \\
\hline 3,4-dimethylanisole (23) & 1141 & & $\mathrm{~ms}, \mathrm{std}$ & $0.2 \%$ \\
\hline 1,4-dimethoxybenzene (22) & 1160 & $1161[25]$ & ms, ri, std & $0.2 \%$ \\
\hline terpinen-4-ol (18) & 1174 & $1174[25]$ & $\mathrm{ms}, \mathrm{ri}$ & $0.1 \%$ \\
\hline 3-oxo-1,8-cineole (17) & 1179 & $1186[25]$ & $\mathrm{ms}, \mathrm{ri}$ & $0.7 \%$ \\
\hline $2 \beta$-hydroxy-1,8-cineole (14) & 1208 & $1217[26]$ & $\mathrm{ms}, \mathrm{ri}$ & $0.4 \%$ \\
\hline 2-oxo-1,8-cineole (16) & 1213 & $1218[27]$ & $\mathrm{ms}$, ri & $<0.1 \%$ \\
\hline 2a-hydroxy-1,8-cineole (15) & 1220 & $1228[26]$ & $\mathrm{ms}, \mathrm{ri}$ & $<0.1 \%$ \\
\hline 2,4,5-trimethylanisole $(\mathbf{2 4})$ & 1225 & & ms, syn & $54.5 \%$ \\
\hline 1,2,3-trimethoxybenzene (21) & 1308 & $1309[28]$ & ms, ri, std & $<0.1 \%$ \\
\hline 2,5-dimethyl-p-anisaldehyde (25) & 1456 & & $\mathrm{~ms}, \mathrm{std}$ & $0.5 \%$ \\
\hline methyl 2,5-dimethyl- $p$-anisate (26) & 1544 & & ms, syn & $0.4 \%$ \\
\hline 1,8-dimethoxynaphthalene (27) & 1657 & $1657[19]$ & ms, ri & $0.3 \%$ \\
\hline pogostol (19) & 1657 & $1651[25]$ & $\mathrm{ms}, \mathrm{ri}$ & $0.3 \%$ \\
\hline
\end{tabular}

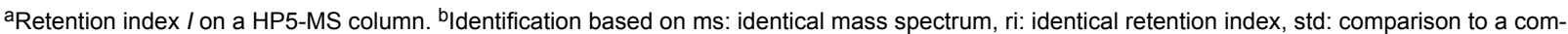
mercially available standard compound, syn: comparison to a synthetic standard. 'Peak area in $\%$ of total peak area. The sum is less than $100 \%$, because compounds originating from the medium, unidentified compounds and contaminants such as plasticisers are not mentioned. 
<smiles>[R]CC(C)CC</smiles><smiles>CCCCCC(=O)CC</smiles>

8

$6(\mathrm{R}=\mathrm{H})$
$7(R=A c)$

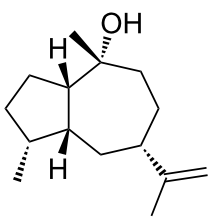

19<smiles>[R]c1cccc(OC)c1OC</smiles>

$20(\mathrm{R}=\mathrm{H})$ $21(\mathrm{R}=\mathrm{OMe})$<smiles>[R]c1ncc(C)nc1[R]</smiles>

$9\left(R^{1}=R^{2}=H\right)$ $10\left(R^{1}=M e, R^{2}=H\right)$ $11\left(R^{1}=R^{2}=M e\right)$ $12\left(R^{1}=M e, R^{2}=E t\right)$

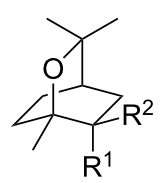

$13\left(R^{1}=R^{2}=H\right)$

$14\left(\mathrm{R}^{1}=\mathrm{H}, \mathrm{R}^{2}=\mathrm{OH}\right)$

$15\left(R^{1}=\mathrm{OH}, \mathrm{R}^{2}=\mathrm{H}\right)$

$16\left(R^{1}=R^{2}=0\right)$<smiles>CC12CC(=O)C(C1)OC2(C)C</smiles>

17

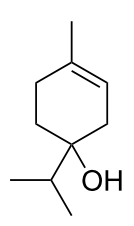

18<smiles>COc1ccc(OC)cc1</smiles>

22<smiles>[X]c1cc(C)c(C)cc1OC</smiles>

$23(\mathrm{R}=\mathrm{H})$ $24(\mathrm{R}=\mathrm{Me})$<smiles>[R]C(=O)c1cc(C)c(OC)cc1C</smiles>

$25(\mathrm{R}=\mathrm{H})$ $26(\mathrm{R}=\mathrm{OMe})$<smiles>COc1cccc2cccc(OC)c12</smiles>

27

Figure 3: Volatiles from Hypoxylon griseobrunneum.

also found. This volatile is frequently accompanied by other $\mathrm{C}_{8}$ metabolites [1], which is reflected for $H$. griseobrunneum by the detection of octan-3-one (8). Trace amounts of a series of alkylated pyrazines including methylpyrazine (9), 2,5-dimethylpyrazine (10), trimethylpyrazine (11) and 2-ethyl-3,6-dimethylpyrazine (12) were also observed. These compounds were previously reported from the actinobacterium Corynebacterium glutamicum in which pyrazines are biosynthetically derived from acetoin and its higher homologs [24]. For unambiguous structure elucidation commercially available standards of 9-11 were used, while a synthesis of $\mathbf{1 2}$ was performed in our earlier study [24].

Furthermore, a group of monoterpenes and the sesquiterpene alcohol pogostol (19) that was previously reported from other fungi $[29,30]$ were observed. Monoterpenes were comprised of terpinen-4-ol (18), 1,8-cineole (13) as one of the major compounds in the extracts, and small amounts of its oxidation products $2 \beta$-hydroxy-1,8-cineole (14), $2 \alpha$-hydroxy-1,8-cineole (15), 2-oxo-1,8-cineole (16) and 3-oxo-1,8-cineole (17). The monoterpene ether $\mathbf{1 3}$ has previously been reported from other Hypoxylon spp. [31] and the responsible monoterpene synthase has been identified [32]. Its hydroxylated derivatives $\mathbf{1 4}$ and $\mathbf{1 5}$ were found in insects feeding on leafs of Melaleuca alternifolia that contain large amounts of 13 [26], and both alcohols 14 and $\mathbf{1 5}$ along with the ketones $\mathbf{1 6}$ and $\mathbf{1 7}$ were reported as metabolites of $\mathbf{1 3}$ in human milk [27].

The mass spectrum of the main compound $\mathbf{2 4}$ from $\mathrm{H}$. griseobrunneum (Figure 4A) showed several fragment ions in the low $\mathrm{m} / \mathrm{z}$ region typical for an aromatic compound, while the frag- ment ion at $m / z=119$ pointed to the loss of a methoxy group from the molecular ion $\left([\mathrm{M}-31]^{+}\right)$, suggesting the structure of a trimethylanisole for $\mathbf{2 4}$. Six constitutional isomers of this compound exist (Table 2). For four of these compounds the corresponding trimethylphenols were commercially available that were O-methylated with methyl iodide and $\mathrm{K}_{2} \mathrm{CO}_{3}$ to yield compounds $24 \mathbf{a}, \mathbf{2 4 b}, \mathbf{2 4 c}$ and $24 \mathrm{e}$. The other two isomers 2,3,4-trimethylanisole (24d) and 2,4,5-trimethylanisole (24) were obtained by ortho-methylation of 3,4-dimethylphenol (28) via a known procedure [33], followed by HPLC purification of the products 2,4,5-trimethylphenol (29a) and 2,3,4-trimethylphenol (29b) and subsequent O-methylation (Scheme 1). Comparison of the GC retention index of the natural product $(I=1225)$ to the retention indices of all six standards narrowed the possible structures down to those of 2,4,5-trimethylanisole $(I=1225)$ and 2,3,5-trimethylanisole $(I=1227)$, while all other isomers could be ruled out. The final structural assignment of 2,4,5-trimethylanisole for $\mathbf{2 4}$ was based on the better matching mass spectrum of this compound in comparison to the alternative of 24c. Compound 24 has not been reported from other natural sources before.

The identification of $\mathbf{2 4}$ was further supported by a feeding experiment with (methyl- ${ }^{2} \mathrm{H}_{3}$ )methionine. While the methylation pattern of the alternative structure $\mathbf{2 4} \mathbf{c}$ is difficult to understand via a polyketide biosynthesis mechanism, the formation of the assigned structure of $\mathbf{2 4}$ by a polyketide synthase (PKS) can be easily rationalised (Scheme 2). The acetate starter unit, bound to the acyl carrier protein (ACP) of an iterative fungal PKS, can be elongated with malonyl-SCoA (mal-SCoA) followed by $\mathrm{C}$-methylation with $S$-adenosyl-L-methionine (SAM). Two 

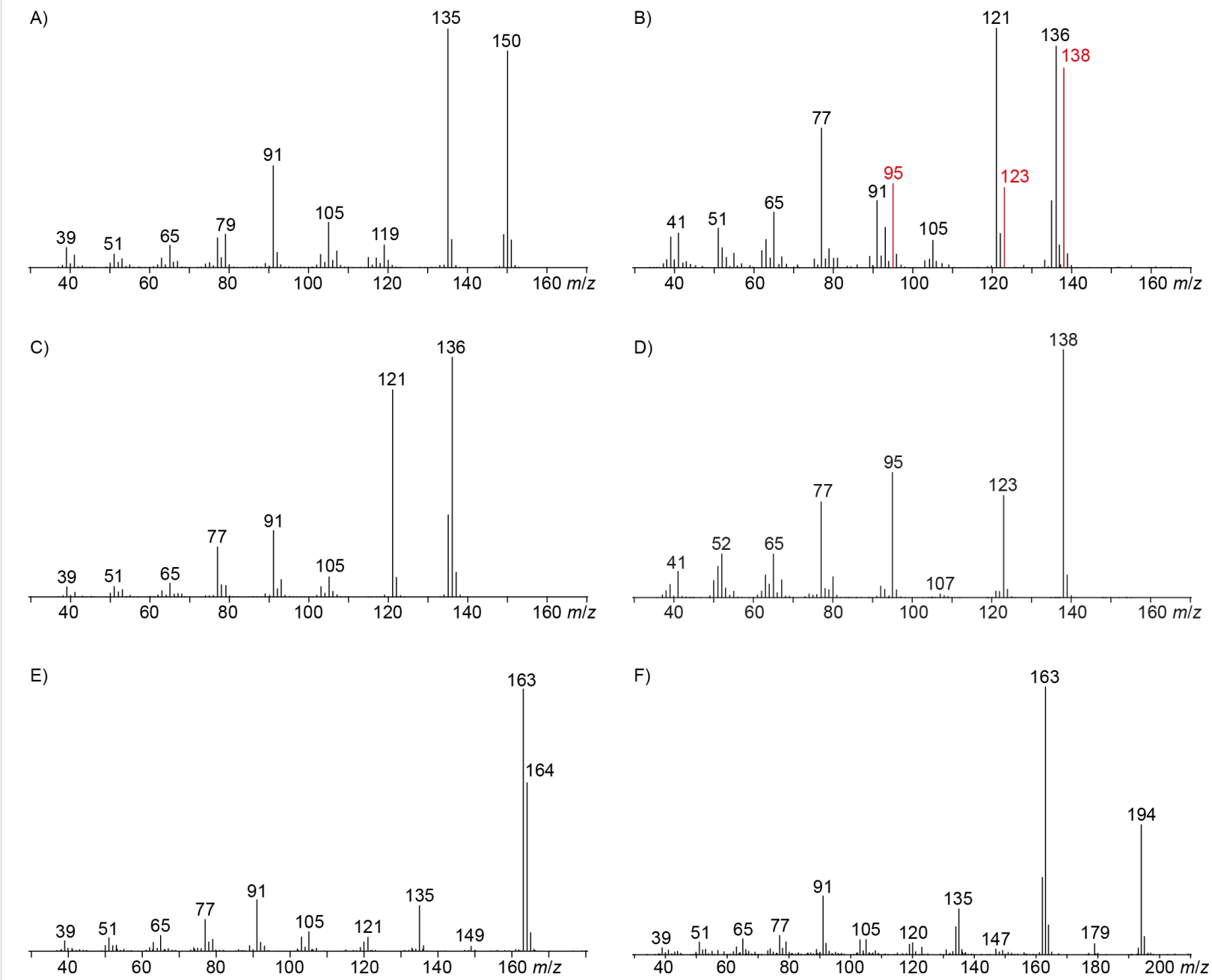

Figure 4: El mass spectra of A) 2,4,5-trimethylanisole (24), B) the coeluting mixture of 3,4-dimethylanisole (23) and veratrole (20) with major peaks originating from 20 shown in red, C) the commercial standard of 23, D) the commercial standard of 20, E) 2,5-dimethyl-p-anisaldehyde (25), F) methyl 2,5-dimethyl-p-anisate (26).

Table 2: Retention indices of all isomers of trimethylanisole.

\begin{tabular}{|c|c|c|}
\hline structure & compound name ${ }^{a}$ & $\rho^{b}$ \\
\hline & 2,4,6-trimethylanisole $(\mathbf{2 4 a})$ & 1157 \\
\hline $\mathrm{Me}$ & 2,3,6-trimethylanisole (24b) & 1181 \\
\hline & 2,4,5-trimethylanisole (24) & 1225 \\
\hline
\end{tabular}


Table 2: Retention indices of all isomers of trimethylanisole. (continued)<smiles>COc1cc(C)cc(C)c1C</smiles><smiles>COc1ccc(C)c(C)c1C</smiles><smiles>COc1cc(C)c(C)c(C)c1</smiles>

aThe natural product from $H$. griseobrunneum is $\mathbf{2 4}$, its isomers are designated $\mathbf{2 4 a - e . ~}{ }^{b}$ Retention index I on a HP5-MS column.<smiles>Cc1ccc(O)cc1C</smiles>

28

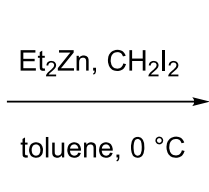

toluene, $0^{\circ} \mathrm{C}$<smiles>Cc1cc(C)c(O)cc1C</smiles>

$29 a$<smiles>Cc1ccc(O)c(C)c1C</smiles>

29b<smiles>COC(=O)OC</smiles>

$\mathrm{MeOH}$<smiles>COc1cc(C)c(C)cc1C</smiles>

24<smiles>COc1ccc(C)c(C)c1C</smiles>

24d

Scheme 1: Synthesis of trimethylanisoles 24 and $\mathbf{2 4 d .}$

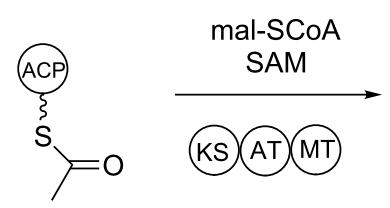<smiles>CC(=O)C(C)C(O)C(C)C(=O)CC(=O)Sc1ccccc1</smiles><smiles>Cc1cc(C)c(O)c(C(=O)Sc2ccccc2)c1C</smiles><smiles>O=C(O)C(=O)O</smiles><smiles>Cc1cc(C)c(O)cc1C</smiles>

$29 a$<smiles>CC(=O)C(C)C(O)C(C)C(=O)Sc1ccccc1</smiles><smiles>O=S(=O)(O)CCc1ccccc1</smiles>

SAM<smiles>COc1cc(C)c(C)cc1C</smiles>

24

Scheme 2: Hypothetical biosynthesis of 24. ACP: acyl carrier protein, AT: acyl transferase, KR: ketoreductase, KS: ketosynthase, mal-SCoA: malonyl-SCoA, MT: methyl transferase, SAM: S-adenosyl-L-methionine.

more rounds of elongation with mal-SCoA, the first extension with C-methylation and action of a ketoreductase (KR), result in a tetraketide intermediate that can be cyclised by aldol conden- sation, followed by elimination of water to result in the aromatic ring system. Thioester hydrolysis and decarboxylation produce 29a that can be converted by SAM-dependent O-meth- 
ylation into 24. In summary, this hypothetical biosynthetic mechanism includes three SAM-dependent methylation steps. A feeding experiment with (methyl- $\left.{ }^{2} \mathrm{H}_{3}\right)$ methionine, the biosynthetic precursor of SAM, resulted in the incorporation of labelling into up to three methyl groups of $\mathbf{2 4}$, but not into the fourth methyl group (Figure 5), which is in line with the biosynthetic model of Scheme 2. Note that because of an isotope effect the isotopomers of $\mathbf{2 4}$ can be separated by gas chromatography depending on their deuterium content $[34,35]$, which makes the usage of (methyl- $\left.{ }^{2} \mathrm{H}_{3}\right)$ methionine superior to the usage of ${ }^{13} \mathrm{C}$-labelled methionine that would not have led to chromato- graphic separation of the isotopomers. In conjunction with the low incorporation rates obtained here, the results would have been difficult to interpret.

Another trace compound emitted by H. griseobrunneum showed a molecular ion at $m / z=136$ and coeluted with exactly the same retention time as a second compound with a molecular ion at $m / z=138$. In case of two coeluting compounds the individual compounds are often enriched in the right and left peak flanks, and their individual mass spectra can be extracted by careful background subtraction, but this was not the case here, so only

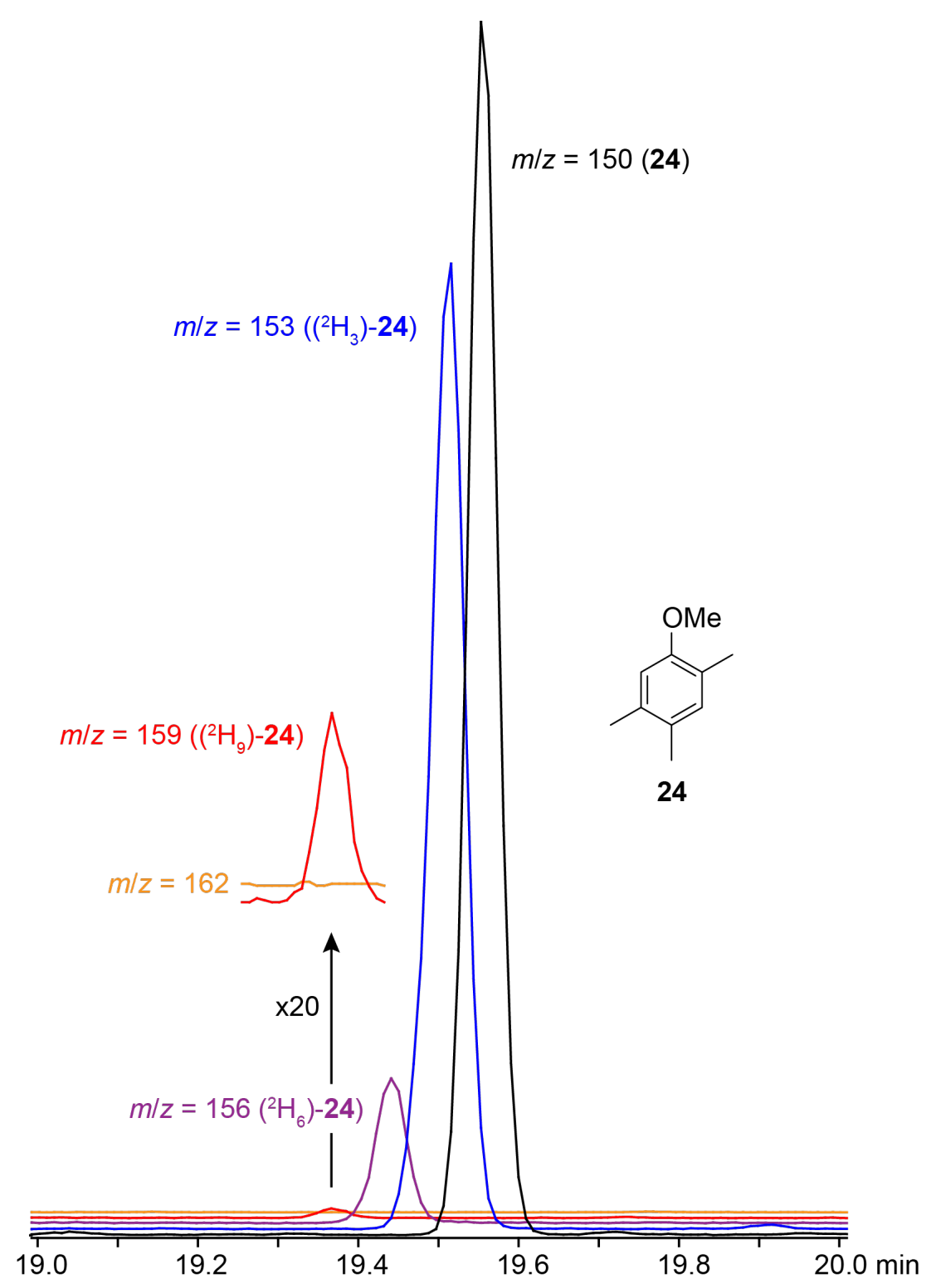

Figure 5: Biosynthesis of 24. Feeding of $\left(\right.$ methyl- $\left.{ }^{2} \mathrm{H}_{3}\right)$ methionine resulted in the incorporation of labelling into up to three methyl groups of $\mathbf{2 4}$. The shown ion trace chromatograms represent unlabelled 24 (black, $m / z=150),\left({ }^{2} \mathrm{H}_{3}\right)-24$ (blue, $\left.m / z=153\right),\left({ }^{2} \mathrm{H}_{6}\right)-24(p u r p l e, m / z=156)$, and $\left({ }^{2} \mathrm{H}_{9}\right)-24$ (red, $m / z=159$ ). No incorporation into the fourth methyl group was observed (no peak visible for $m / z=162$ ). For the ion trace chromatograms of $m / z=159$ and 162 also expansions $(20 x)$ are shown. 
the mass spectrum of the compound mixture was obtained (Figure 4B). The analysis of the observed fragment ions suggested that the compound with the molecular ion at $\mathrm{m} / \mathrm{z}=136$ may be one of the isomers of dimethylanisole, explaining the fragment ion at $m / z=105$ by the loss of the methoxy group $\left([\mathrm{M}-31]^{+}\right)$, and in agreement with the $14 \mathrm{Da}$ lower molecular ion in comparison to 24. All six isomers of dimethylanisole were commercially available and a comparison of retention indices together with a personal inspection of the mixed mass spectrum of Figure 4B and the mass spectrum of 3,4-dimethylanisole (Figure 4C) unequivocally identified the natural product as 3,4-dimethylanisole (23, Table 3). Furthermore, the alternative structure of a trimethylphenol was ruled out, because all the isomers eluted later than $\mathbf{2 3}$ (Table 3 ). Interestingly, the elution order of the trimethylphenols is the same as for the corresponding trimethylanisoles with respect to their substitution patterns, and each trimethylphenol consistently elutes slightly later with an increase of the retention index by ca. $30-50$ points than the trimethylanisole analogue (Table 2 and Table 3), which is explainable by the significantly higher polarity of the phenols compared to the anisoles. Compound $\mathbf{2 3}$ was recently reported from Euphorbia golondrina [36], but was never observed as a fungal natural product so far.

Biosynthetically, the identified compound $\mathbf{2 3}$ can arise by a similar mechanism as discussed for $\mathbf{2 4}$, potentially as a minor product of the same PKS, only the C-methylation step in the second round of chain extension needs to be skipped

Table 3: Retention indices of all isomers of dimethylanisole and trimethylphenol.

structure<smiles>COc1c(C)cccc1C</smiles><smiles>COc1ccc(C)cc1C</smiles><smiles>COc1cc(C)ccc1C</smiles><smiles>COc1cc(C)cc(C)c1</smiles><smiles>COc1cccc(C)c1C</smiles><smiles>COc1ccc(C)c(C)c1</smiles><smiles>Cc1cc(C)c(O)c(C)c1</smiles><smiles>Cc1ccc(C)c(O)c1C</smiles>

compound name ${ }^{a}$

2,6-dimethylanisole (23a) 1056

2,4-dimethylanisole (23b)

2,5-dimethylanisole (23c) 
Table 3: Retention indices of all isomers of dimethylanisole and trimethylphenol. (continued)<smiles>Cc1cc(C)c(O)cc1C</smiles>

2,4,5-trimethylphenol (23h)<smiles>Cc1cc(C)c(C)c(O)c1</smiles><smiles>Cc1ccc(O)c(C)c1C</smiles><smiles>Cc1cc(O)cc(C)c1C</smiles>

1262

${ }^{\mathrm{a}}$ The natural product from $H$. griseobrunneum is $\mathbf{2 3}$, its isomers are designated $\mathbf{2 3 a - k}{ }^{\mathrm{b}}$ Retention index / on a HP5-MS column.

(Scheme 2). However, during the feeding experiment with ( methyl $-{ }^{2} \mathrm{H}_{3}$ )methionine the formation of $\mathbf{2 3}$ was suppressed, possibly because the additional supply of methionine resulted in a higher efficiency of the programmed methylation steps towards 24.

The additional signals in the mixed mass spectrum (Figure 4B) at $m / z=138,123$ and 95 that do not originate from $\mathbf{2 3}$ are present with similar relative proportions as in the mass spec- trum of veratrole (20, Figure 4D), and indeed a commercial standard of $\mathbf{2 0}$ revealed the same retention index of $I=1141$ as the natural product, thus confirming the structure of veratrole for the second of the coeluting compounds. Its isomer 1,4dimethoxybenzene (22) and a trimethoxybenzene $\mathbf{2 1}$ were also detected. Comparison to all three commercially available isomers of trimethoxybenzene established the identity of $\mathbf{2 1}$ as 1,2,3-trimethoxybenzene (Table 4). 1,8-Dimethoxynaphthalene (27) was also found and has been reported previously from

Table 4: Retention indices of all isomers of trimethoxybenzene.

structure<smiles>COc1cccc(OC)c1OC</smiles><smiles>COc1ccc(OC)c(OC)c1</smiles><smiles>COc1cc(OC)cc(OC)c1</smiles>

compound name

1,2,3-trimethoxybenzene (21)

1,2,4-trimethoxybenzene (21a)

1,3,5-trimethoxybenzene (21b) $p^{b}$

1368

1409

\footnotetext{
aThe natural product from $H$. griseobrunneum is $\mathbf{2 1}$, its isomers are designated $\mathbf{2 1 a}$ and $\mathbf{2 1} \mathbf{b}$. ${ }^{\mathrm{b}}$ Retention index I on a HP5-MS column.
} 
other Hypoxylon spp. [19,37]. The corresponding compound 1,8-dihydroxynaphthalene is a known precursor of fungal melanin pigments [38].

Two trace compounds exhibited the mass spectra shown in Figure 4E and Figure 4F that were similar to database spectra of 2,5-dimethyl- $p$-anisaldehyde (25) and methyl 2,5-dimethyl- $p$ anisate (26). The substitution pattern of these compounds is well explained by polyketide biosynthesis logic (Scheme 3). Starting from ACP-bound acetate, two non-reducing elongations with malonyl-SCoA, the first without and the second with C-methylation, followed by another elongation with reduction of the 3-oxo group and cyclisation yields the aromatic system of 25 and 26. Hydrolytic cleavage from the ACP and two methylations of the phenol and the carboxylic acid result in $\mathbf{2 6}$, while reductive cleavage and methylation of the phenol give $\mathbf{2 5}$. The aldehyde $\mathbf{2 5}$ was commercially available and matched the natural product in terms of mass spectrum and retention time. Compound 25 was transformed into the corresponding methyl ester by treatment with iodine and potassium hydroxide in methanol [39]. The obtained material also showed identical behaviour in the GC-MS analysis to natural 26. Both compounds $\mathbf{2 5}$ and $\mathbf{2 6}$ are new natural products.

\section{Identification of volatiles from Hypoxylon macrocarpum}

The composition of the headspace extracts from H. macrocarpum (Figure 6 and Table 5) was completely different from the extracts of $H$. griseobrunneum with only the three compounds 2,5-dimethylpyrazine (10), trimethylpyrazine (11) and pogostol (19) being emitted by both species (Figure 7). The volatiles benzaldehyde (32) and 2-phenylethanol (35) as two of the main compounds, and the trace compounds 2-acetylfuran (30), 2-acetylthiazole (31), acetophenone (33), 1-phenylethanol (34), 1-phenylpropan-1,2-dione (36) and $m$-cresol (37) were readily identified from their mass spectra and retention indices and by comparison to authentic standards.

The main compounds released by $H$. macrocarpum were identified as 3,4-dimethoxytoluene (43) and 4-methylsalicylaldehyde (39), while 2,5-dimethylphenol (38) and 2-methoxy-4-methylbenzaldehyde (40) were detected in lower amounts. All four compounds were previously observed in the bouquet of $H$. invadens and unambiguously identified by comparison to all possible isomers with different ring substitution patterns [19]. Furthermore, comparison to all ten isomers of methoxy-methylbenzaldehydes described in this study allowed for the identifica-
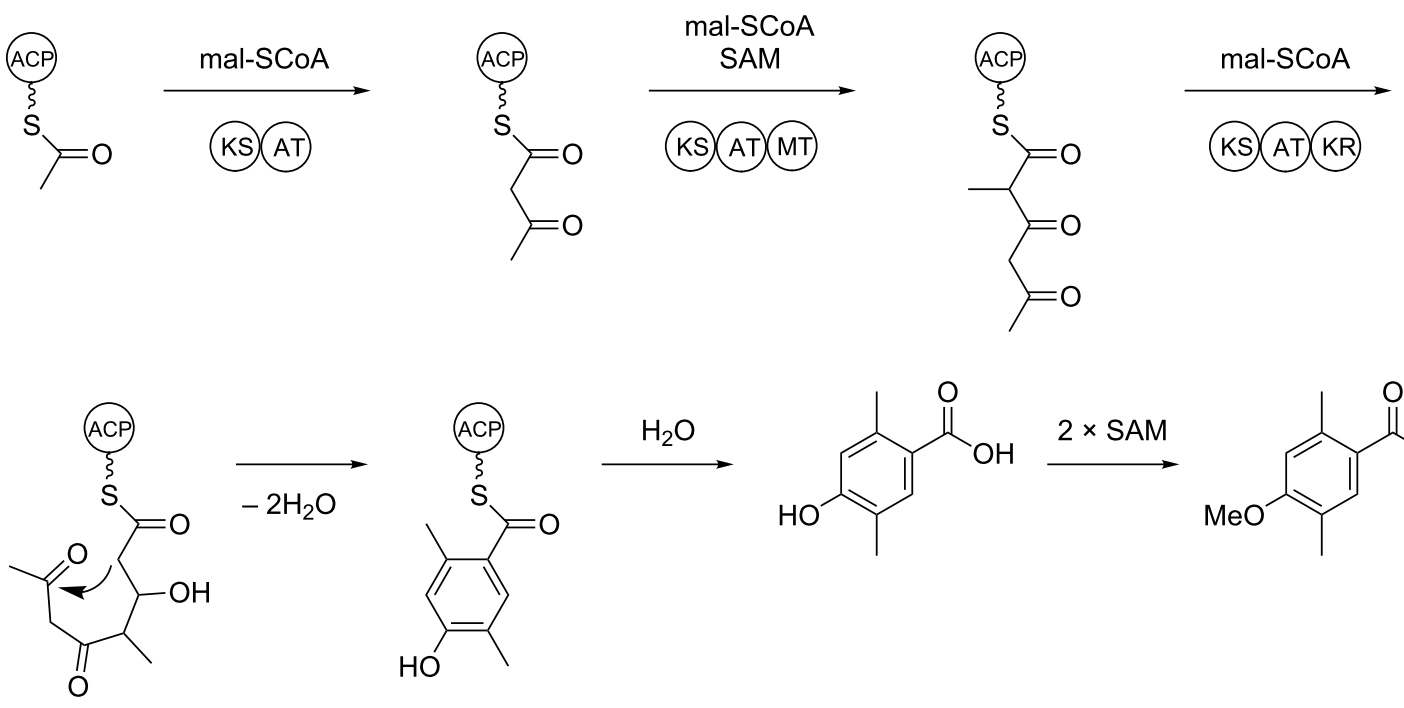<smiles>Cc1cc(C(=O)Sc2ccccc2)c(C)cc1O</smiles><smiles>Cc1cc(C(=O)O)c(C)cc1O</smiles><smiles>COC(=O)c1cc(C)c(OC)cc1C</smiles><smiles>Cc1cc(C=O)c(C)cc1O</smiles><smiles>[Mg][Mg]</smiles><smiles>COc1cc(C)c(C=O)cc1C</smiles> 


\section{3}

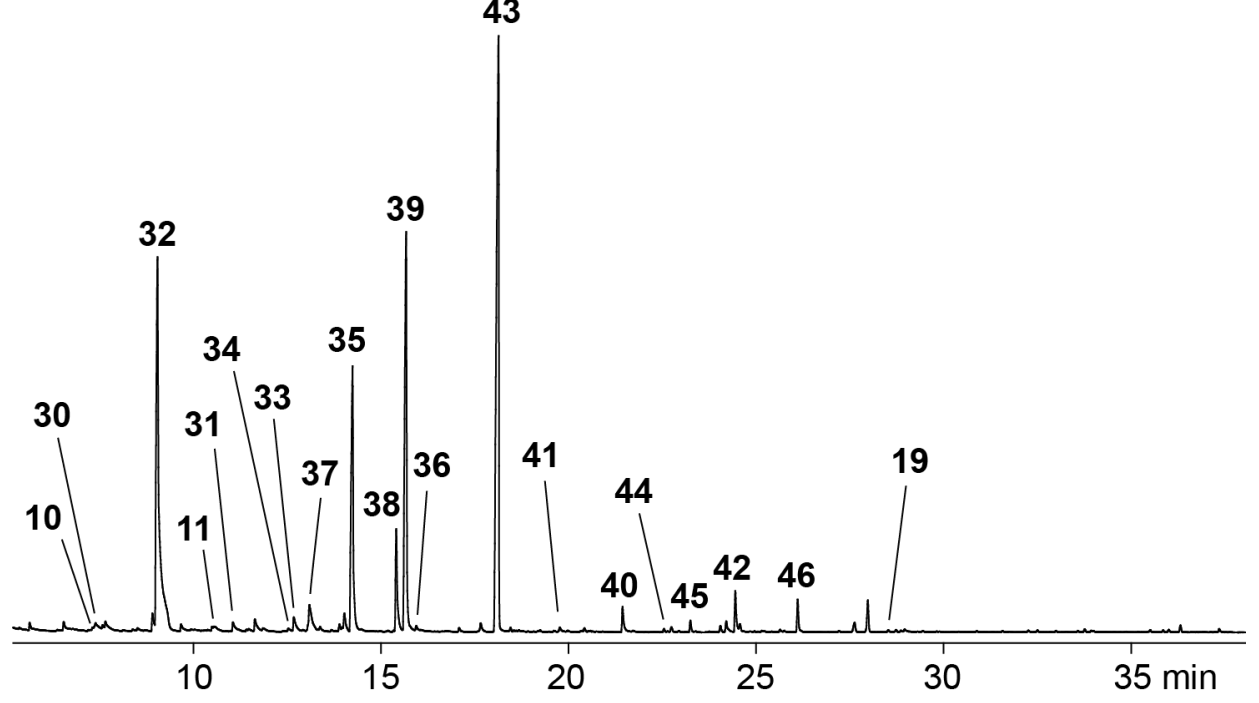

Figure 6: Total ion chromatogram of a CLSA headspace extract from Hypoxylon macrocarpum STMA 130423. Peak numbers refer to compound numbers in Table 5 and in Figure 7.

Table 5: Volatiles identified in headspace extract from Hypoxylon macrocarpum STMA 130423.

\begin{tabular}{|c|c|c|c|c|}
\hline compound & $P^{a}$ & $I$ (lit.) & identification $^{b}$ & peak area $^{\mathrm{c}}$ \\
\hline 2,5-dimetylpyrazine (10) & 903 & $908[25]$ & ms, ri, std & $0.1 \%$ \\
\hline 2-acetylfuran $(30)$ & 906 & 909 [25] & ms, ri, std & $0.7 \%$ \\
\hline benzaldehyde (32) & 952 & $952[25]$ & ms, ri, std & $22.8 \%$ \\
\hline trimethylpyrazine (11) & 995 & $1000[25]$ & ms, ri, std & $0.5 \%$ \\
\hline 2-acetylthiazole (31) & 1012 & $1014[25]$ & ms, ri, std & $0.6 \%$ \\
\hline 1-phenylethanol (34) & 1054 & $1057[25]$ & ms, ri, std & $0.1 \%$ \\
\hline acetophenone (33) & 1059 & $1059[25]$ & ms, ri, std & $0.8 \%$ \\
\hline$m$-cresol (37) & 1071 & $1072[25]$ & $\mathrm{ms}, \mathrm{ri}$ & $1.9 \%$ \\
\hline 2-phenylethanol (35) & 1105 & $1106[25]$ & ms, ri, std & $11.6 \%$ \\
\hline 2,5-dimethylphenol (38) & 1154 & $1152[19]$ & ms, ri, std & $3.6 \%$ \\
\hline 4-methylsalicylaldehyde (39) & 1162 & $1165[19]$ & ms, ri, std & $16.4 \%$ \\
\hline 1-phenylpropan-1,2-dione (36) & 1171 & $1175[40]$ & $\mathrm{ms}, \mathrm{ri}$ & $0.1 \%$ \\
\hline 3,4-dimethoxytoluene (43) & 1243 & $1240[19]$ & ms, ri, std & $29.1 \%$ \\
\hline 3-methoxy-4-methylbenzaldehyde (41) & 1302 & $1307[19]$ & ms, ri, std & $0.2 \%$ \\
\hline 2-methoxy-4-methylbenzaldehyde (40) & 1365 & $1364[19]$ & ms, ri, std & $0.9 \%$ \\
\hline 3,4,5-trimethoxytoluene (44) & 1405 & & $\mathrm{~ms}$, std & $0.1 \%$ \\
\hline 2,4,5-trimethoxytoluene (45) & 1436 & & ms, syn & $0.3 \%$ \\
\hline 3,4-dimethoxybenzaldehyde (42) & 1483 & $1475[25]$ & $\mathrm{ms}$, ri, std & $1.3 \%$ \\
\hline 2,5-dichloro-1,3-dimethoxybenzene (46) & 1552 & $1556[18]$ & ms, ri, std & $1.0 \%$ \\
\hline pogostol (19) & 1657 & $1651[25]$ & ms, ri & $<0.1 \%$ \\
\hline
\end{tabular}

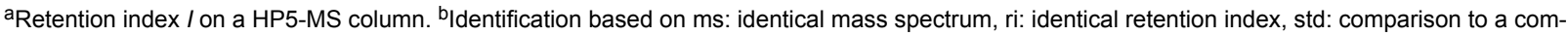
mercially available standard compound, syn: comparison to a synthetic standard. 'Peak area in \% of total peak area. The sum is less than $100 \%$, because compounds originating from the medium, unidentified compounds and contaminants such as plasticisers are not mentioned.

tion of another trace compound from H. macrocarpum as 3-methoxy-4-methylbenzaldehyde (41). The chlorinated compound 2,5-dichloro-1,3-dimethoxybenzene (46) was also rigorously identified by comparison to all possible regioisomers that we had synthesised in a previous study [18]. Interestingly, the sub- stitution pattern for the compound from H. macrocarpum is different to an isomer from the endophyte Geniculosporium sp. that was identified as 1,5-dichloro-2,3-dimethoxybenzene. Compound 46 has not been described as a natural product before. Another trace compound released by H. macrocarpum 
<smiles>CC(=O)c1ccco1</smiles>

30<smiles>CC(=O)c1nccs1</smiles>

31<smiles>[R]C(=O)c1ccccc1</smiles>

$32(\mathrm{R}=\mathrm{H})$ $33(\mathrm{R}=\mathrm{Me})$<smiles>CC(O)c1ccccc1</smiles>

34<smiles>OCCc1ccccc1</smiles>

35<smiles>CC(=O)C(=O)c1ccccc1</smiles>

36<smiles>[R]c1ccc(C)cc1O</smiles>

$37(\mathrm{R}=\mathrm{H})$ $38(R=M e)$<smiles>[R]Oc1cc(C)ccc1C=O</smiles>

$39(\mathrm{R}=\mathrm{H})$ $40(\mathrm{R}=\mathrm{Me})$<smiles>[R]c1ccc(C=O)cc1OC</smiles>

$41(\mathrm{R}=\mathrm{Me})$

$42(\mathrm{R}=\mathrm{OMe})$<smiles>[R]c1cc(C)cc(OC)c1OC</smiles>

$43(\mathrm{R}=\mathrm{H})$

$44(\mathrm{R}=\mathrm{OMe})$<smiles>COc1cc(OC)c(OC)cc1C</smiles>

45<smiles>COc1cc(Cl)cc(OC)c1Cl</smiles>

46

Figure 7: Volatiles from Hypoxylon macrocarpum.

exhibited a mass spectrum that pointed to the structure of a dimethoxybenzaldehyde (Figure 8A). Comparison to all six commercially available isomers (Table 6 ) showed the identity of the natural product and 3,4-dimethoxybenzaldehyde (42).

Finally, two trace compounds with almost identical mass spectra (Figure 8B and Figure 8C), but clear separation by gas chromatography, were suggested to be trimethoxytoluenes. Two isomers, 3,4,5-trimethoxytoluene (44) and 2,4,6-trimethoxy- toluene (44d), were commercially available. 2,3,4-Trimethoxybenzaldehyde (47) was reduced to 2,3,4-trimethoxytoluene (44a) using $\mathrm{PdCl}_{2}$ and $\mathrm{Et}_{3} \mathrm{SiH}$ [41] (Scheme 4), while the other three isomers were synthesised according to reported procedures [42-44]. Comparison of all six isomers to the two natural products (Table 7) resulted in their identification as 3,4,5trimethoxytoluene (44) and 2,4,5-trimethoxytoluene (45). While 44 is a relatively widespread natural product, its isomer $\mathbf{4 5}$ has only once been tentatively identified by mass spectrometry in
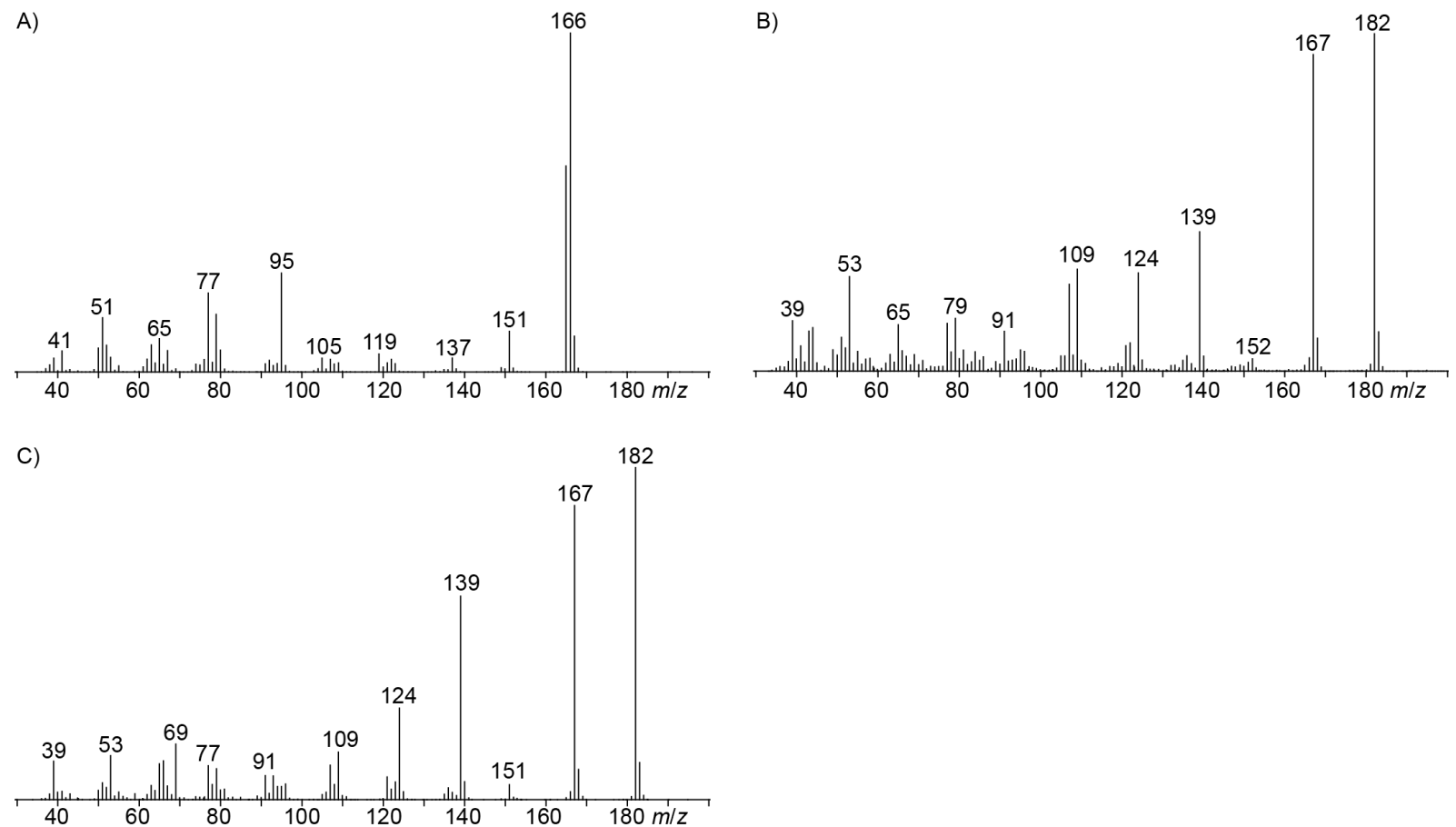

Figure 8: El mass spectra of A) 3,4-dimethoxybenzaldehyde (42), B) 3,4,5-trimethoxytoluene (44), and C) 2,4,5-trimethoxytoluene (45). 


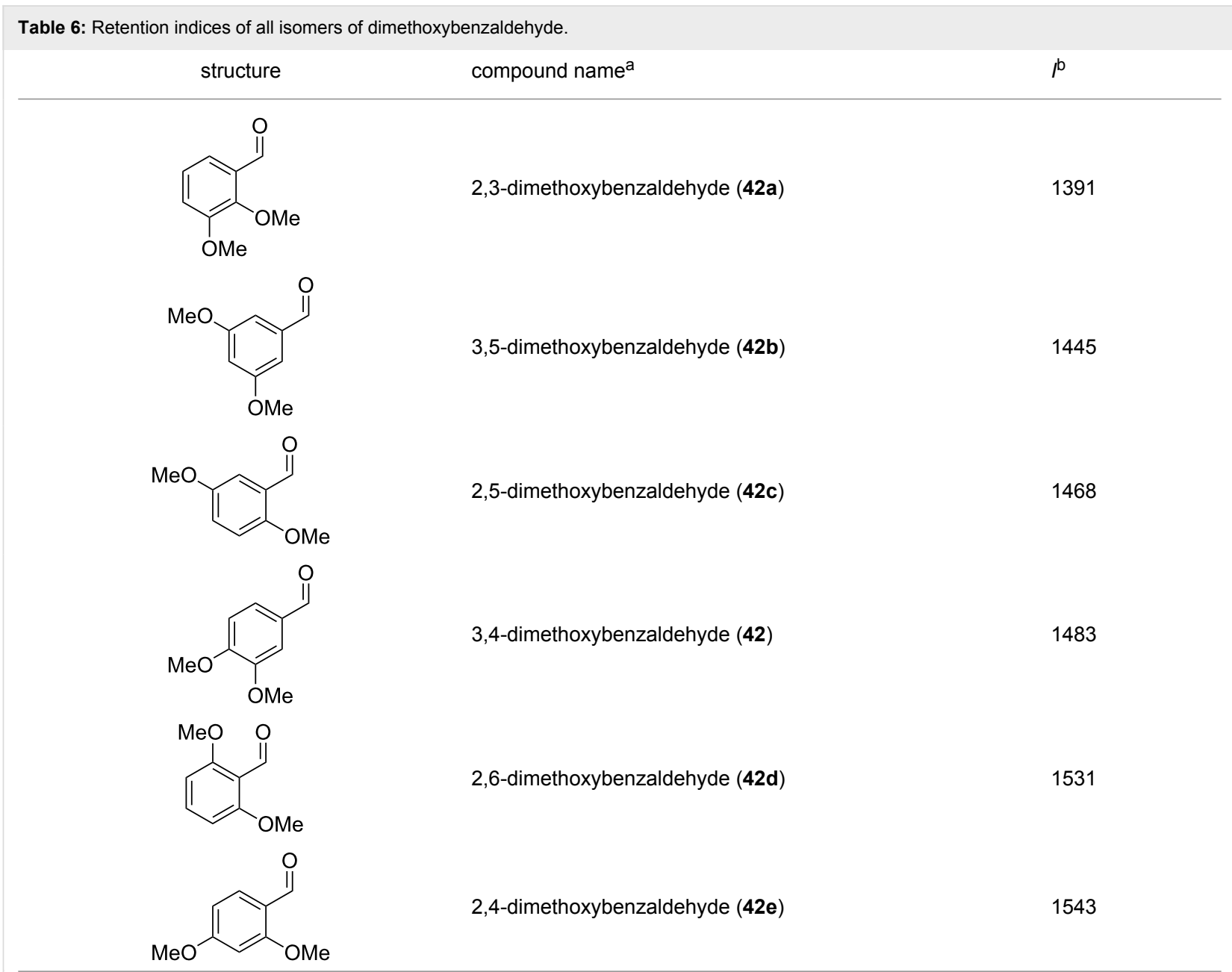

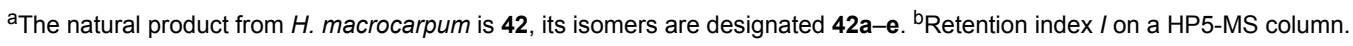<smiles>COc1ccc(C=O)c(OC)c1OC</smiles>

47

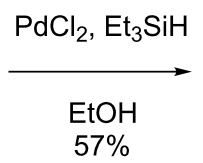

$57 \%$

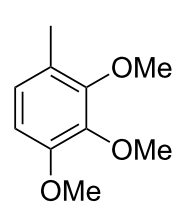

$44 a$
Scheme 4: Synthesis of 2,3,4-trimethoxytoluene (44a).

plants from the genus Asarum [45], but never from fungi before. However, it remains unclear how $\mathbf{4 5}$ was distinguished from $\mathbf{4 4}$ or other possible isomers in the earlier study.

\section{Conclusion}

Both investigated ascomycetes, Hypoxylon griseobrunneum and Hypoxylon macrocarpum, were found to emit complex mixtures of volatiles, mainly composed of aromatic compounds. As we have demonstrated, for unequivocal structural assignments based solely on GC-MS data it is important to compare the natural product to all possible constitutional isomers with different ring substitution patterns, because the mass spectra of these isomers are too similar to rely solely on MS data for compound identification. Therefore, also the retention index of the natural product must match the retention index of an authentic standard, and usually the retention indices of the isomeric aromatic compounds with different substitution patterns are sufficiently different for a confident structural assignment. Also biosynthetic considerations can help in the structure elucidation, because some aromatic substitution patterns are in line with a polyketide biosynthesis mechanism, while other substitution patterns may be difficult to understand. But such considerations should be made with care and should ideally be supported, e.g., by feeding experiments, as we have conducted in the present study. The main compounds of $H$. griseobrunneum were 2-methylbutan-1-ol, 1,8-cineol and 2,4,5-trimethylanisole, while $H$. macrocarpum released a completely different bouquet with the main compounds benzaldehyde, 2-phenylethanol, 
Table 7: Retention indices of all isomers of trimethoxytoluene.

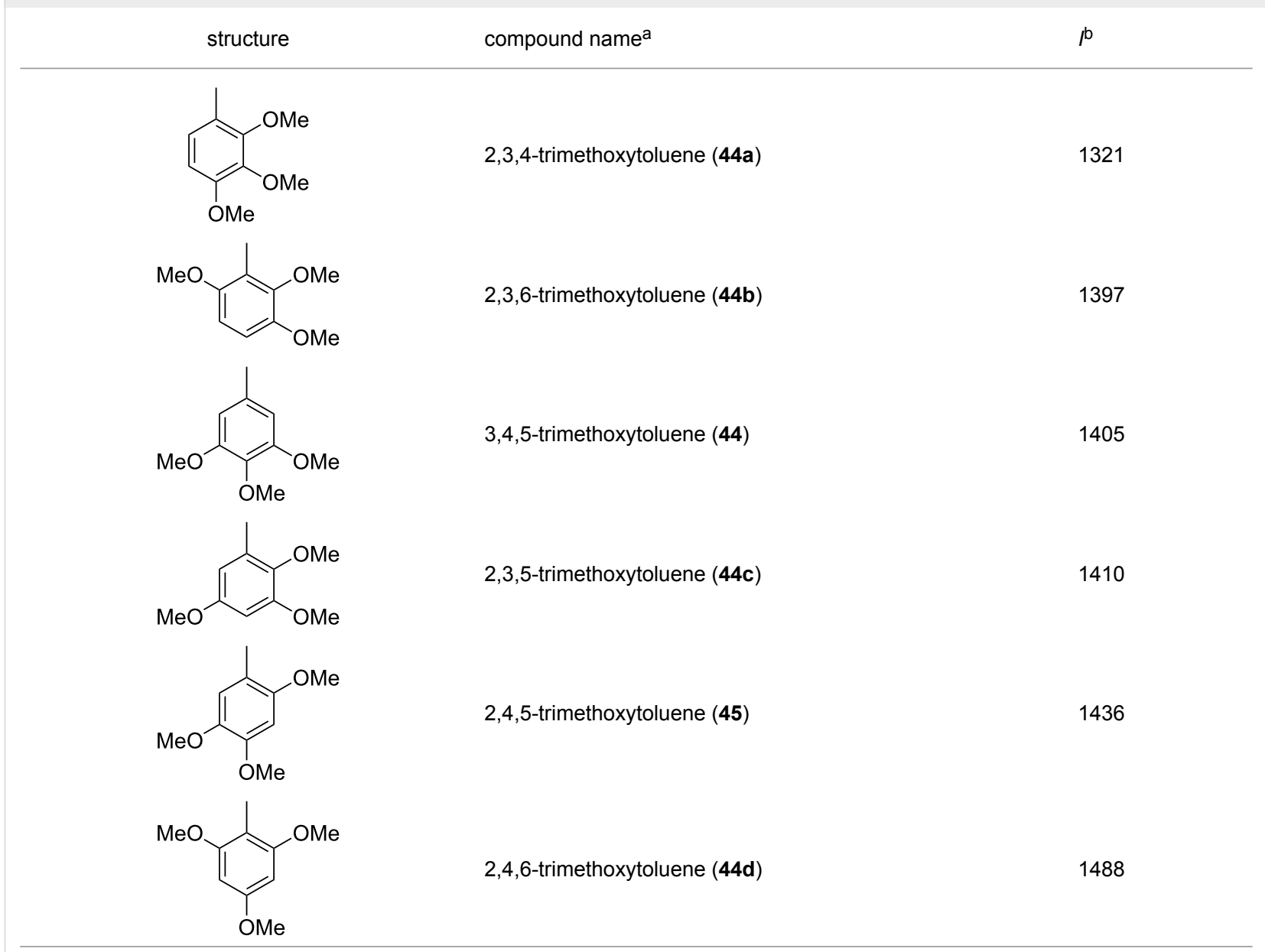

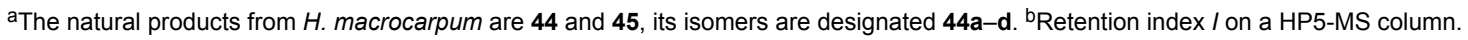

4-methylsalicylaldehyde and 3,4-dimethoxytoluene. All these volatiles exhibit a characteristic smell and are likely main contributors to the odour produced by the fungi, but also some of the identified minor compounds may be important for the fungal fragrance. Notably, fungi of the genus Hypoxylon are interesting sources of new natural products, as exemplified by the identification of 2,4,5-trimethylanisole, 2,5-dimethyl- $p$ anisaldehyde and its corresponding methyl ester, and 2,5dichloro-1,3-dimethoxybenzene. Therefore, it will be of high interest to investigate the volatiles from further Hypoxylon species in the near future.

\section{Experimental}

\section{Strains and culture conditions}

Hypoxylon griseobrunneum was obtained from a specimen collected in Martinique, Case Pilote, on a trail to Morne Venté on wood and bark of a dead dicotyledon branch in a mesophilic to xerophilic forest, on 25 August 2010 by Jacques Fournier [46]. A voucher specimen is deposited at the herbarium of the
University of Lille, France (LIP, No MJF10120) and the culture is deposited with MUCL (Louvain-la Neuve, Belgium) under the accession number MUCL 53754.

Hypoxylon macrocarpum was obtained from ascospores of a specimen collected in Germany, Rhineland-Palatinate Province in the vicinity of Forst, near the Pechsteinkopf from wood of Fagus on 20 October 2012 by Benno and Marc Stadler [21]. A voucher specimen is deposited in the fungarium of the Helmholtz Centre for Infection Research (HZI, Braunschweig, Germany) under the accession number STMA 130423.

\section{Analysis of volatiles}

The volatiles emitted by agar plate cultures of $H$. griseobrunneum and H. macrocarpum were collected through a closedloop stripping apparatus (CLSA) [13] for ca. 1 day at room temperature and under natural light-dark rhythm. The CLSA charcoal filter traps were extracted with $\mathrm{CH}_{2} \mathrm{Cl}_{2}(50 \mu \mathrm{L}$, HPLC grade), followed by analysis of the extracts by GC-MS. 


\section{GC-MS}

GC-MS analyses were performed with a 7890A GC coupled to a 5975C inert mass detector (Agilent, Hewlett-Packard Company, Wilmington, USA). The GC was equipped with a HP5-MS fused silica capillary column (30 m, $0.25 \mathrm{~mm}$ i. d., $0.25 \mu \mathrm{m}$ film, Agilent). Conditions were inlet pressure: $77.1 \mathrm{kPa}$, He $23.3 \mathrm{~mL} \mathrm{~min}^{-1}$; injection volume: $1.5 \mu \mathrm{L}$; injector operation mode: splitless ( $60 \mathrm{~s}$ valve time); carrier gas: He at $1.2 \mathrm{~mL} \mathrm{~min}^{-1}$; GC program: $5 \mathrm{~min}$ at $50{ }^{\circ} \mathrm{C}$, then increasing with $5{ }^{\circ} \mathrm{C} \mathrm{min}-1$ to $320{ }^{\circ} \mathrm{C}$; transfer line $300{ }^{\circ} \mathrm{C}$; electron energy $70 \mathrm{eV}$. Retention indices $(I)$ were determined from a homologous series of $n$-alkanes $\left(\mathrm{C}_{8}-\mathrm{C}_{38}\right)$.

\section{Synthesis of 2,4,5-trimethylphenol (29a) and 2,3,4-trimethylphenol (29b)}

Diiodomethane (2.14 g, $8.0 \mathrm{mmol}, 2$ equiv) was dissolved in dry toluene $(3 \mathrm{~mL})$ under an argon atmosphere and the solution was cooled to $0{ }^{\circ} \mathrm{C}$. To the vigorously stirred solution, $\mathrm{Et}_{2} \mathrm{Zn}$ in toluene $(5.0 \mathrm{~mL}, 1.2 \mathrm{M}, 6.0 \mathrm{mmol}, 1.5$ equiv) was added rapidly, followed immediately by the addition of 3,4dimethylphenol (500 mg, $4.0 \mathrm{mmol})$ in toluene $(3 \mathrm{~mL})$. The reaction mixture was stirred at $0{ }^{\circ} \mathrm{C}$ for $5 \mathrm{~min}$ and then under reflux for $1.5 \mathrm{~h}$. The reaction mixture was cooled to $0{ }^{\circ} \mathrm{C}$ and then quenched with an aqueous solution of $\mathrm{NaHCO}_{3}$ $(10 \% \mathrm{w} / \mathrm{w})$. The aqueous phase was extracted with diethyl ether for three times and the combined organic layers were dried over $\mathrm{MgSO}_{4}$. The solvent was removed under reduced pressure and the crude product was purified by column chromatography on silica gel (cyclohexane/ethyl acetate $5: 1$ ). The obtained product contained 29a and 29b as a mixture which was separated by HPLC (KNAUER Wissenschaftliche Geräte GmbH, Berlin, Azura; DAICEL Chiralpak IA column, $5 \mu \mathrm{m}, 4.6 \times 250 \mathrm{~mm}$; hexane/2-propanol 95:5; retention times: $9.66 \mathrm{~min}(\mathbf{2 9 b})$ and $10.89 \mathrm{~min}(\mathbf{2 9 a}))$. The pure products were obtained as colourless liquids.

2,4,5-Trimethylphenol (29a). Yield: $14 \mathrm{mg}$ (0.10 mmol, 3\%). ${ }^{1} \mathrm{H} \mathrm{NMR}\left(500 \mathrm{MHz}, \mathrm{CDCl}_{3}, 298 \mathrm{~K}\right) \delta(\mathrm{ppm}) 6.88(\mathrm{~s}, 1 \mathrm{H}, \mathrm{CH})$, 6.59 (s, 1H, CH), 4.56 (br s, 1H, OH), $2.20\left(\mathrm{~s}, 3 \mathrm{H}, \mathrm{CH}_{3}\right), 2.19$ $\left(\mathrm{s}, 3 \mathrm{H}, \mathrm{CH}_{3}\right), 2.16\left(\mathrm{~s}, 3 \mathrm{H}, \mathrm{CH}_{3}\right) ;{ }^{13} \mathrm{C} \mathrm{NMR}(125 \mathrm{MHz}$, $\left.\mathrm{CDCl}_{3}, 298 \mathrm{~K}\right) \delta(\mathrm{ppm}) 151.6\left(\mathrm{C}_{\mathrm{q}}\right), 135.2\left(\mathrm{C}_{\mathrm{q}}\right), 132.1(\mathrm{CH})$, $128.4\left(\mathrm{C}_{\mathrm{q}}\right), 120.5\left(\mathrm{C}_{\mathrm{q}}\right), 116.3(\mathrm{CH}), 19.4\left(\mathrm{CH}_{3}\right), 18.7\left(\mathrm{CH}_{3}\right)$, $15.2\left(\mathrm{CH}_{3}\right)$.

2,3,4-Trimethylphenol (29b). Yield: $11 \mathrm{mg}$ (0.08 mmol, 2\%). ${ }^{1} \mathrm{H}$ NMR $\left(500 \mathrm{MHz}, \mathrm{CDCl}_{3}, 298 \mathrm{~K}\right) \delta(\mathrm{ppm}) 6.87(\mathrm{~d}$, $\left.{ }^{3} J=8.1 \mathrm{~Hz}, 1 \mathrm{H}, \mathrm{CH}\right), 6.56\left(\mathrm{~d},{ }^{3} J=8.1 \mathrm{~Hz}, 1 \mathrm{H}, \mathrm{CH}\right), 4.54$ (br s, $1 \mathrm{H}, \mathrm{OH}), 2.22\left(\mathrm{~s}, 3 \mathrm{H}, \mathrm{CH}_{3}\right), 2.20\left(\mathrm{~s}, 3 \mathrm{H}, \mathrm{CH}_{3}\right), 2.19(\mathrm{~s}, 3 \mathrm{H}$, $\left.\mathrm{CH}_{3}\right) ;{ }^{13} \mathrm{C} \mathrm{NMR}\left(125 \mathrm{MHz}, \mathrm{CDCl}_{3}, 298 \mathrm{~K}\right) \delta(\mathrm{ppm}) 151.7\left(\mathrm{C}_{\mathrm{q}}\right)$, $136.6\left(\mathrm{C}_{\mathrm{q}}\right), 128.8\left(\mathrm{C}_{\mathrm{q}}\right), 127.5(\mathrm{CH}), 122.6\left(\mathrm{C}_{\mathrm{q}}\right), 112.0(\mathrm{CH})$, $20.3\left(\mathrm{CH}_{3}\right), 16.0\left(\mathrm{CH}_{3}\right), 12.1\left(\mathrm{CH}_{3}\right)$.

\section{Synthesis of trimethylanisoles $\mathbf{2 4}$ and $\mathbf{2 4 a - e}$}

To a solution of the respective phenol derivative (23f-k, $15.0 \mathrm{mg}, 0.11 \mathrm{mmol}, 1$ equiv) in dry DMF (2.2 mL), $\mathrm{K}_{2} \mathrm{CO}_{3}$ (15.2 $\mathrm{mg}, 0.11 \mathrm{mmol}, 1$ equiv) was added and the mixture was stirred at room temperature for $30 \mathrm{~min}$. Methyl iodide $(31 \mathrm{mg}$, $0.22 \mathrm{mmol}, 2$ equiv) was added and the reaction mixture was stirred at room temperature overnight. The reaction was quenched by addition of water and the aqueous phase was extracted three times with EtOAc. The combined organic layers were dried over $\mathrm{MgSO}_{4}$ and the solvent was removed under reduced pressure. The crude product was purified by column chromatography on silica gel (cyclohexane/ethyl acetate 20:1). The pure products were obtained as pale yellow liquids.

2,4,5-Trimethylanisole (24). Yield: $5 \mathrm{mg}$ (0.03 mmol, 32\%). TLC (silica, cyclohexane/ethyl acetate 20:1): $R_{\mathrm{f}}=0.48$; ${ }^{1} \mathrm{H}$ NMR $\left(500 \mathrm{MHz}, \mathrm{CDCl}_{3}, 298 \mathrm{~K}\right) \delta(\mathrm{ppm}) 6.89(\mathrm{~s}, 1 \mathrm{H}, \mathrm{CH})$, $6.63(\mathrm{~s}, 1 \mathrm{H}, \mathrm{CH}), 3.80\left(\mathrm{~s}, 3 \mathrm{H}, \mathrm{CH}_{3}\right), 2.23\left(\mathrm{~s}, 3 \mathrm{H}, \mathrm{CH}_{3}\right), 2.17$ (s, $\left.3 \mathrm{H}, \mathrm{CH}_{3}\right), 2.16\left(\mathrm{~s}, 3 \mathrm{H}, \mathrm{CH}_{3}\right) ;{ }^{13} \mathrm{C} \mathrm{NMR}\left(125 \mathrm{MHz}, \mathrm{CDCl}_{3}\right.$, $298 \mathrm{~K}) \delta(\mathrm{ppm}) 155.8\left(\mathrm{C}_{\mathrm{q}}\right), 134.6\left(\mathrm{C}_{\mathrm{q}}\right), 132.1(\mathrm{CH}), 128.0\left(\mathrm{C}_{\mathrm{q}}\right)$, $123.6\left(\mathrm{C}_{\mathrm{q}}\right), 112.1(\mathrm{CH}), 55.7\left(\mathrm{CH}_{3}\right), 20.0\left(\mathrm{CH}_{3}\right), 18.8\left(\mathrm{CH}_{3}\right)$, $15.7\left(\mathrm{CH}_{3}\right)$.

2,4,6-Trimethylanisole (24a). Yield: $6 \mathrm{mg}$ (0.04 mmol; 36\%). TLC (silica, cyclohexane/ethyl acetate 20:1): $R_{\mathrm{f}}=0.31$; ${ }^{1} \mathrm{H}$ NMR $\left(500 \mathrm{MHz}, \mathrm{CDCl}_{3}, 298 \mathrm{~K}\right) \delta(\mathrm{ppm}) 6.82(\mathrm{~s}, 2 \mathrm{H}$, $2 \times \mathrm{CH}), 3.70\left(\mathrm{~s}, 3 \mathrm{H}, \mathrm{CH}_{3}\right), 2.25\left(\mathrm{~s}, 6 \mathrm{H}, 2 \times \mathrm{CH}_{3}\right), 2.24(\mathrm{~s}, 3 \mathrm{H}$, $\left.\mathrm{CH}_{3}\right) ;{ }^{13} \mathrm{C} \mathrm{NMR}\left(125 \mathrm{MHz}, \mathrm{CDCl}_{3}, 298 \mathrm{~K}\right) \delta(\mathrm{ppm}) 154.9\left(\mathrm{C}_{\mathrm{q}}\right)$, $133.2\left(\mathrm{C}_{\mathrm{q}}\right), 130.6\left(2 \times \mathrm{C}_{\mathrm{q}}\right), 129.5(2 \times \mathrm{CH}), 59.9\left(\mathrm{CH}_{3}\right), 20.8$ $\left(\mathrm{CH}_{3}\right), 16.1\left(2 \times \mathrm{CH}_{3}\right)$.

2,3,6-Trimethylanisole (24b). Yield: $7 \mathrm{mg}$ (0.05 mmol; 42\%). TLC (silica, cyclohexane/ethyl acetate 20:1): $R_{\mathrm{f}}=0.42$; ${ }^{1} \mathrm{H}$ NMR (400 MHz, $\left.\mathrm{CDCl}_{3}, 298 \mathrm{~K}\right) \delta(\mathrm{ppm}) 6.92(\mathrm{~d}$, $\left.{ }^{3} J=7.6 \mathrm{~Hz}, 1 \mathrm{H}, \mathrm{CH}\right), 6.83\left(\mathrm{~d},{ }^{3} J=7.6 \mathrm{~Hz}, 1 \mathrm{H}, \mathrm{CH}\right), 3.70(\mathrm{~s}$, $\left.3 \mathrm{H}, \mathrm{CH}_{3}\right), 2.27\left(\mathrm{~s}, 3 \mathrm{H}, \mathrm{CH}_{3}\right), 2.24\left(\mathrm{~s}, 3 \mathrm{H}, \mathrm{CH}_{3}\right), 2.20(\mathrm{~s}, 3 \mathrm{H}$, $\left.\mathrm{CH}_{3}\right) ;{ }^{13} \mathrm{C} \mathrm{NMR}\left(100 \mathrm{MHz}, \mathrm{CDCl}_{3}, 298 \mathrm{~K}\right) \delta(\mathrm{ppm}) 156.9\left(\mathrm{C}_{\mathrm{q}}\right)$, $136.0\left(\mathrm{C}_{\mathrm{q}}\right), 129.6\left(\mathrm{C}_{\mathrm{q}}\right), 128.2\left(\mathrm{C}_{\mathrm{q}}\right), 128.0(\mathrm{CH}), 125.3(\mathrm{CH})$, $60.0\left(\mathrm{CH}_{3}\right), 20.0\left(\mathrm{CH}_{3}\right), 16.2\left(\mathrm{CH}_{3}\right), 12.4\left(\mathrm{CH}_{3}\right)$.

2,3,5-Trimethylanisole (24c). Yield: $8 \mathrm{mg}$ (0.05 mmol; 48\%). TLC (silica, cyclohexane/ethyl acetate 20:1): $R_{\mathrm{f}}=0.47$; ${ }^{1} \mathrm{H}$ NMR $\left(400 \mathrm{MHz}, \mathrm{CDCl}_{3}, 298 \mathrm{~K}\right) \delta(\mathrm{ppm}) 6.62(\mathrm{~s}, 1 \mathrm{H}, \mathrm{CH})$, $6.55(\mathrm{~s}, 1 \mathrm{H}, \mathrm{CH}), 3.81\left(\mathrm{~s}, 3 \mathrm{H}, \mathrm{CH}_{3}\right), 2.30\left(\mathrm{~s}, 3 \mathrm{H}, \mathrm{CH}_{3}\right), 2.24$ (s, $\left.3 \mathrm{H}, \mathrm{CH}_{3}\right), 2.11\left(\mathrm{~s}, 3 \mathrm{H}, \mathrm{CH}_{3}\right) ;{ }^{13} \mathrm{C} \mathrm{NMR}\left(100 \mathrm{MHz}, \mathrm{CDCl}_{3}\right.$, $298 \mathrm{~K}) \delta(\mathrm{ppm}) 157.6\left(\mathrm{C}_{\mathrm{q}}\right), 137.7\left(\mathrm{C}_{\mathrm{q}}\right), 135.6\left(\mathrm{C}_{\mathrm{q}}\right), 123.1(\mathrm{CH})$, $121.9\left(\mathrm{C}_{\mathrm{q}}\right), 109.0(\mathrm{CH}), 55.7\left(\mathrm{CH}_{3}\right), 21.5\left(\mathrm{CH}_{3}\right), 20.1\left(\mathrm{CH}_{3}\right)$, $11.4\left(\mathrm{CH}_{3}\right)$.

2,3,4-Trimethylanisole (24d). Yield: $5 \mathrm{mg}$ (0.03 mmol, 32\%). TLC (silica, cyclohexane/ethyl acetate 20:1): $R_{\mathrm{f}}=0.54$; 
${ }^{1} \mathrm{H}$ NMR (400 MHz, $\left.\mathrm{CDCl}_{3}, 298 \mathrm{~K}\right) \delta(\mathrm{ppm}) 6.96(\mathrm{~d}$, $\left.{ }^{3} J=8.3 \mathrm{~Hz}, 1 \mathrm{H}, \mathrm{CH}\right), 6.64\left(\mathrm{~d},{ }^{3} J=8.3 \mathrm{~Hz}, 1 \mathrm{H}, \mathrm{CH}\right), 3.79(\mathrm{~s}$, $\left.3 \mathrm{H}, \mathrm{CH}_{3}\right), 2.23\left(\mathrm{~s}, 3 \mathrm{H}, \mathrm{CH}_{3}\right), 2.18\left(\mathrm{~s}, 3 \mathrm{H}, \mathrm{CH}_{3}\right), 2.17(\mathrm{~s}, 3 \mathrm{H}$, $\left.\mathrm{CH}_{3}\right) ;{ }^{13} \mathrm{C}$ NMR $\left(100 \mathrm{MHz}, \mathrm{CDCl}_{3}, 298 \mathrm{~K}\right) \delta(\mathrm{ppm}) 156.0\left(\mathrm{C}_{\mathrm{q}}\right)$, $136.4\left(\mathrm{C}_{\mathrm{q}}\right), 128.6\left(\mathrm{C}_{\mathrm{q}}\right), 127.2(\mathrm{CH}), 125.1\left(\mathrm{C}_{\mathrm{q}}\right), 107.8(\mathrm{CH})$, $55.8\left(\mathrm{CH}_{3}\right), 20.3\left(\mathrm{CH}_{3}\right), 16.0\left(\mathrm{CH}_{3}\right), 12.1\left(\mathrm{CH}_{3}\right)$.

3,4,5-Trimethylanisole (24e). Yield: $8 \mathrm{mg}$ (0.05 mmol; 48\%). TLC (silica, cyclohexane: ethyl acetate $=20: 1$ ): $R_{\mathrm{f}}=0.37$; ${ }^{1} \mathrm{H} \mathrm{NMR}\left(400 \mathrm{MHz}, \mathrm{CDCl}_{3}, 298 \mathrm{~K}\right) \delta(\mathrm{ppm}) 6.59(\mathrm{~s}, 2 \mathrm{H}$, $2 \times \mathrm{CH}), 3.77\left(\mathrm{~s}, 3 \mathrm{H}, \mathrm{CH}_{3}\right), 2.27\left(\mathrm{~s}, 6 \mathrm{H}, 2 \times \mathrm{CH}_{3}\right), 2.11(\mathrm{~s}, 3 \mathrm{H}$, $\left.\mathrm{CH}_{3}\right) ;{ }^{13} \mathrm{C} \mathrm{NMR}\left(100 \mathrm{MHz}, \mathrm{CDCl}_{3}, 298 \mathrm{~K}\right) \delta(\mathrm{ppm}) 157.1\left(\mathrm{C}_{\mathrm{q}}\right)$, $137.7\left(2 \times \mathrm{C}_{\mathrm{q}}\right), 127.2\left(\mathrm{C}_{\mathrm{q}}\right), 113.2(\mathrm{CH}), 55.3\left(\mathrm{CH}_{3}\right), 21.0$ $\left(2 \times \mathrm{CH}_{3}\right), 14.7\left(\mathrm{CH}_{3}\right)$.

\section{Synthesis of methyl 2,5-dimethyl-p-anisate} (26)

Similar to a reported procedure [39], 2,5-dimethyl- $p$-anisaldehyde $(\mathbf{2 5}, 1 \mathrm{~g}, 6.09 \mathrm{mmol}, 1$ equiv) was dissolved in $\mathrm{MeOH}$ $(60 \mathrm{~mL})$ and the solution was cooled to $0{ }^{\circ} \mathrm{C}$. Solutions of $\mathrm{KOH}$ ( $1.045 \mathrm{~g}, 15.89 \mathrm{mmol}, 2.6$ equiv, in $20 \mathrm{~mL} \mathrm{MeOH}$ ) and $\mathrm{I}_{2}$ ( $2.01 \mathrm{~g}, 7.92 \mathrm{mmol}, 1.3$ equiv, in $10 \mathrm{~mL} \mathrm{MeOH}$ ) were added and the mixture was stirred for $90 \mathrm{~min}$ at $0{ }^{\circ} \mathrm{C}$. The reaction was diluted with EtOAc, washed three times with saturated aqueous $\mathrm{Na}_{2} \mathrm{~S}_{2} \mathrm{O}_{3}$ solution and subsequently with brine. The organic layer was dried over $\mathrm{MgSO}_{4}$ and the solvent was removed under reduced pressure. The crude product was purified via column chromatography (cyclohexane/ethyl acetate 10:1) on silica gel and the pure product was obtained as a colourless solid (277 mg, $1.43 \mathrm{mmol}, 23 \%$ ). TLC (silica, cyclohexane/ ethyl acetate 3:1): $R_{\mathrm{f}}=0.67 .{ }^{1} \mathrm{H}$ NMR $\left(500 \mathrm{MHz}, \mathrm{CDCl}_{3}\right.$, $298 \mathrm{~K}) \delta(\mathrm{ppm}) 7.75(\mathrm{~s}, 1 \mathrm{H}, \mathrm{CH}), 6.64(\mathrm{~s}, 1 \mathrm{H}, \mathrm{CH}), 3.86(\mathrm{~s}, 3 \mathrm{H}$, $\left.\mathrm{CH}_{3}\right), 3.85$ (s, 3H, $\left.\mathrm{CH}_{3}\right), 2.60$ (s, 3H, $\left.\mathrm{CH}_{3}\right), 2.18\left(\mathrm{~s}, 3 \mathrm{H}, \mathrm{CH}_{3}\right)$; ${ }^{13} \mathrm{C}$ NMR $\left(125 \mathrm{MHz}, \mathrm{CDCl}_{3}, 298 \mathrm{~K}\right) \delta(\mathrm{ppm}) 167.9\left(\mathrm{C}_{\mathrm{q}}\right), 160.6$ $\left(\mathrm{C}_{\mathrm{q}}\right), 140.8\left(\mathrm{C}_{\mathrm{q}}\right), 133.4(\mathrm{CH}), 123.9\left(\mathrm{C}_{\mathrm{q}}\right), 120.9\left(\mathrm{C}_{\mathrm{q}}\right), 112.9$ $(\mathrm{CH}), 55.5\left(\mathrm{CH}_{3}\right), 51.6\left(\mathrm{CH}_{3}\right), 22.1\left(\mathrm{CH}_{3}\right), 15.8\left(\mathrm{CH}_{3}\right)$.

\section{Synthesis of 2,3,4-trimethoxytoluene (44a)}

According to a known procedure [41], to a solution of 2,3,4trimethoxybenzaldehyde $(47,500 \mathrm{mg}, 2.55 \mathrm{mmol}, 1$ equiv) in EtOH (13 mL), $\mathrm{SiEt}_{3} \mathrm{H}$ (590 mg, $5.1 \mathrm{mmol}, 2$ equiv) was added under an argon atmosphere. $\mathrm{PdCl}_{2}(45.2 \mathrm{mg}, 0.26 \mathrm{mmol}$, $10 \mathrm{~mol} \%$ ) was added and after stirring for $1 \mathrm{~h}$, the reaction was quenched with $\mathrm{H}_{2} \mathrm{O}$. The mixture was extracted three times with $\mathrm{Et}_{2} \mathrm{O}$ and the combined organic layers were dried over $\mathrm{MgSO}_{4}$. The solvent was removed under reduced pressure and the crude product was purified via column chromatography on silica gel (cyclohexane/ethyl acetate 10:1). The pure product was obtained as a colourless liquid (267 mg, $1.47 \mathrm{mmol}, 57 \%)$. TLC (silica, cyclohexane/ethyl acetate $3: 1$ ): $R_{\mathrm{f}}=0.50 ;{ }^{1} \mathrm{H}$ NMR $\left(500 \mathrm{MHz}, \mathrm{C}_{6} \mathrm{D}_{6}, 298 \mathrm{~K}\right) \delta(\mathrm{ppm}) 6.73\left(\mathrm{dq},{ }^{3} J=8.4 \mathrm{~Hz}\right.$, $\left.{ }^{4} J=0.8 \mathrm{~Hz}, 1 \mathrm{H}, \mathrm{CH}\right), 6.38\left(\mathrm{~d},{ }^{3} J=8.4 \mathrm{~Hz}, 1 \mathrm{H}, \mathrm{CH}\right), 3.78(\mathrm{~s}$, $\left.3 \mathrm{H}, \mathrm{CH}_{3}\right), 3.71\left(\mathrm{~s}, 3 \mathrm{H}, \mathrm{CH}_{3}\right), 3.38\left(\mathrm{~s}, 3 \mathrm{H}, \mathrm{CH}_{3}\right), 2.22(\mathrm{~d}$, $\left.{ }^{4} J=0.8 \mathrm{~Hz}, 3 \mathrm{H}, \mathrm{CH}_{3}\right) ;{ }^{13} \mathrm{C} \mathrm{NMR}\left(125 \mathrm{MHz}, \mathrm{C}_{6} \mathrm{D}_{6}, 298 \mathrm{~K}\right)$ $\delta(\mathrm{ppm}) 152.9\left(\mathrm{C}_{\mathrm{q}}\right), 152.8\left(\mathrm{C}_{\mathrm{q}}\right), 143.5\left(\mathrm{C}_{\mathrm{q}}\right), 124.7(\mathrm{CH}), 124.3$ $\left(\mathrm{C}_{\mathrm{q}}\right), 108.0(\mathrm{CH}), 60.6\left(\mathrm{CH}_{3}\right), 60.3\left(\mathrm{CH}_{3}\right), 55.8\left(\mathrm{CH}_{3}\right), 15.9$ $\left(\mathrm{CH}_{3}\right)$.

\section{Acknowledgements}

This work was funded by the DFG (DI1536/9-1). We thank Andreas Schneider (Bonn) for compound purification by preparative HPLC and Jacques Fournier (Rimont, France) and Eric Kuhnert (Leibniz University Hannover) for their previous support in the characterisation of the H. griseobrunneum strain.

\section{ORCID ${ }^{\circledR} \mathrm{iDs}$}

Marc Stadler - https://orcid.org/0000-0002-7284-8671 Jeroen S. Dickschat - https://orcid.org/0000-0002-0102-0631

\section{References}

1. Dickschat, J. S. Nat. Prod. Rep. 2017, 34, 310-328. doi:10.1039/c7np00003k

2. Kimura, M.; Tokai, T.; Takahashi-Ando, N.; Ohsato, S.; Fujimura, M. Biosci., Biotechnol., Biochem. 2007, 71, 2105-2123. doi:10.1271/bbb.70183

3. Wei, C.-M.; McLaughlin, C. S. Biochem. Biophys. Res. Commun. 1974, 57, 838-844. doi:10.1016/0006-291x(74)90622-6

4. Riclea, R.; Dickschat, J. S. Angew. Chem., Int. Ed. 2015, 54, 12167-12170. doi:10.1002/anie.201506128

5. García-Estrada, C.; Martín, J.-F. Appl. Microbiol. Biotechnol. 2016, 100, 8303-8313. doi:10.1007/s00253-016-7788-x

6. Jeleń, H. H. J. Agric. Food Chem. 2002, 50, 6569-6574. doi:10.1021/jf020311o

7. Murahashi, S. Sci. Pap. Inst. Phys. Chem. Res. (Jpn.) 1938, 34, 155-172.

8. Zawirska-Wojtasiak, R. Food Chem. 2004, 86, 113-118. doi:10.1016/j.foodchem.2003.08.016

9. Kandasamy, D.; Gershenzon, J.; Hammerbacher, A. J. Chem. Ecol. 2016, 42, 952-969. doi:10.1007/s10886-016-0768-x

10. Citron, C. A.; Junker, C.; Schulz, B.; Dickschat, J. S. Angew. Chem., Int. Ed. 2014, 53, 4346-4349. doi:10.1002/anie.201402290

11. Collins, R. P.; Halim, A. F. J. Agric. Food Chem. 1972, 20, 437-438. doi:10.1021/jf60180a010

12. Wickel, S. M.; Citron, C. A.; Dickschat, J. S. Eur. J. Org. Chem. 2013, 2906-2913. doi:10.1002/ejoc.201300049

13. Grob, K.; Zürcher, F. J. Chromatogr. A 1976, 117, 285-294. doi:10.1016/0021-9673(76)80005-2

14. Dickschat, J. S. Nat. Prod. Rep. 2014, 31, 838-861. doi:10.1039/c3np70080a

15. Kováts, E. Helv. Chim. Acta 1958, 41, 1915-1932. doi:10.1002/hlca.19580410703

16. Wang, T.; Mohr, K. I.; Stadler, M.; Dickschat, J. S. Beilstein J. Org. Chem. 2018, 14, 135-147. doi:10.3762/bjoc.14.9

17. Dickschat, J. S.; Celik, E.; Brock, N. L. Beilstein J. Org. Chem. 2018, 14, 900-910. doi:10.3762/bjoc.14.77 
18. Wang, T.; Rabe, P.; Citron, C. A.; Dickschat, J. S.

Beilstein J. Org. Chem. 2013, 9, 2767-2777. doi:10.3762/bjoc.9.311

19. Dickschat, J. S.; Wang, T.; Stadler, M. Beilstein J. Org. Chem. 2018, 14, 734-746. doi:10.3762/bjoc.14.62

20. Helaly, S. E.; Thongbai, B.; Stadler, M. Nat. Prod. Rep. 2018, 35, 992-1014. doi:10.1039/c8np00010g

21. Pažoutová, S.; Follert, S.; Bitzer, J.; Keck, M.; Surup, F.; Šrůtka, P.; Holuša, J.; Stadler, M. Fungal Diversity 2013, 60, 107-123. doi:10.1007/s13225-013-0238-5

22. Pouzar, Z. Czech Mycol. 1978, 32, 19-21.

23. Mühlbauer, A.; Triebel, D.; Persoh, D.; Wollweber, H.; Seip, S.; Stadler, M. Mycol. Progress 2002, 1, 235-248. doi:10.1007/s11557-006-0021-z

24. Dickschat, J. S.; Wickel, S.; Bolten, C. J.; Nawrath, T.; Schulz, S.; Wittmann, C. Eur. J. Org. Chem. 2010, 2687-2695. doi:10.1002/ejoc.201000155

25. Adams, R. P. Identification of Essential Oil Components by Gas Chromatography/Mass Spectrometry; Allured: Carol Stream, 2009.

26. Southwell, I. A.; Russell, M. F.; Maddox, C. D. A.; Wheeler, G. S. J. Chem. Ecol. 2003, 29, 83-94. doi:10.1023/a:1021976513603

27. Kirsch, F.; Horst, K.; Röhrig, W.; Rychlik, M.; Buettner, A. Metabolomics 2013, 9, 483-496. doi:10.1007/s11306-012-0466-9

28. Wu, S.; Zorn, H.; Krings, U.; Berger, R. G. Flavour Fragrance J. 2007, 22, 53-60. doi:10.1002/ffj.1758

29. Amand, S.; Langenfeld, A.; Blond, A.; Dupont, J.; Nay, B.; Prado, S. J. Nat. Prod. 2012, 75, 798-801. doi:10.1021/np2009913

30. Barra, L.; Schulz, B.; Dickschat, J. S. ChemBioChem 2014, 15, 2379-2383. doi:10.1002/cbic.201402298

31. Tomsheck, A. R.; Strobel, G. A.; Booth, E.; Geary, B.; Spakowicz, D.; Knighton, B.; Floerchinger, C.; Sears, J.; Liarzi, O.; Ezra, D. Microb. Ecol. 2010, 60, 903-914. doi:10.1007/s00248-010-9759-6

32. Shaw, J. J.; Berbasova, T.; Sasaki, T.; Jefferson-George, K.; Spakowicz, D. J.; Dunican, B. F.; Portero, C. E.; Narváez-Trujillo, A.; Strobel, S. A. J. Biol. Chem. 2015, 290, 8511-8526. doi:10.1074/jbc.m114.636159

33. Lehnert, E. K.; Scott Sawyer, J.; Macdonald, T. L. Tetrahedron Lett. 1989, 30, 5215-5218. doi:10.1016/s0040-4039(01)93745-1

34. Dickschat, J. S.; Wenzel, S. C.; Bode, H. B.; Müller, R.; Schulz, S. ChemBioChem 2004, 5, 778-787. doi:10.1002/cbic.200300813

35. Dickschat, J. S.; Zell, C.; Brock, N. L. ChemBioChem 2010, 11, 417-425. doi:10.1002/cbic.200900668

36. Ndam, L. M.; Mih, A. M.; Tening, A. S.; Fongod, A. G. N.; Temenu, N. A.; Fujii, Y. SpringerPlus 2016, 5, 264. doi:10.1186/s40064-016-1928-8

37. Chang, C.-W.; Chang, H.-S.; Cheng, M.-J.; Liu, T.-W.; Hsieh, S.-Y.; Yuan, G.-F.; Chen, I.-S. Chem. Biodiversity 2014, 11, 949-961. doi:10.1002/cbdv.201300364

38. Bell, A. A.; Wheeler, M. H. Annu. Rev. Phytopathol. 1986, 24, 411-451. doi:10.1146/annurev.py.24.090186.002211

39. Citron, C. A.; Rabe, P.; Barra, L.; Nakano, C.; Hoshino, T.; Dickschat, J. S. Eur. J. Org. Chem. 2014, 7684-7691. doi:10.1002/ejoc.201403002

40. Wang, Q.; Yang, Y.; Zhao, X.; Zhu, B.; Nan, P.; Zhao, J.; Wang, L.; Chen, F.; Liu, Z.; Zhong, Y. Food Chem. 2006, 98, 52-58. doi:10.1016/j.foodchem.2005.04.033

41. Mirza-Aghayan, M.; Boukherroub, R.; Rahimifard, M.; Zadmard, R. J. Iran. Chem. Soc. 2011, 8, 570-573. doi:10.1007/bf03249092

42. Buccini, M.; Punch, K. A.; Kaskow, B.; Flematti, G. R.; Skelton, B. W.; Abraham, L. J.; Piggott, M. J. Org. Biomol. Chem. 2014, 12, 1100-1113. doi:10.1039/c3ob42333f
43. O'Hora, P. S.; Incerti-Pradillos, C. A.; Kabeshov, M. A.; Shipilovskikh, S. A.; Rubtsov, A. E.; Elsegood, M. R. J.; Malkov, A. V. Chem. - Eur. J. 2015, 21, 4551-4555. doi:10.1002/chem.201500176

44. Takaya, Y.; Hotta, R.; Fujiwara, K.; Otani, R.; Uchiyama, Y.; Sakakibara, M.; Fukuda, E.; Niwa, M.; Inouye, K.; Oohata, A. A. Org. Lett. 2014, 16, 3660-3663. doi:10.1021/ol5014119

45. Hayashi, N.; Ding, J.; Ding, Z.; Chen, Z.; Yi, Y.; Komae, H. Z. Naturforsch., C: J. Biosci. 1990, 45c, 32-36. doi:10.1515/znc-1990-1-207

46. Kuhnert, E.; Fournier, J.; Peršoh, D.; Luangsa-ard, J. J. D.; Stadler, M. Fungal Diversity 2014, 64, 181-203. doi:10.1007/s13225-013-0264-3

\section{License and Terms}

This is an Open Access article under the terms of the Creative Commons Attribution License

(http://creativecommons.org/licenses/by/4.0). Please note that the reuse, redistribution and reproduction in particular requires that the authors and source are credited.

The license is subject to the Beilstein Journal of Organic Chemistry terms and conditions: (https://www.beilstein-journals.org/bjoc)

The definitive version of this article is the electronic one which can be found at: doi:10.3762/bjoc. 14.277 